\title{
Under Socialistloven
}

\section{Træk af sønderjysk arbejderbevægelses udvikling 1878-90}

\section{Af Dorrit Andersen}

I årene fra 1878 til 1890 søgte de tyske myndigheder at stække det fremvoksende socialdemokrati ved forbud mod møder, sammenslutninger m.v. Alligevel voksede arbejderbevægelsen i styrke i disse år, og det voldte bekymring hos de danske ledere. Landsarkivar Dorrit Andersen, Odense, fortæller her om de år, hvor socialdemokraterne måtte fare en skyggetilværelse - og om deres forhold til den organiserede danskhed.

\section{Indledning}

Den 19. oktober 1878 vedtog den tyske rigsdag den såkaldte Socialistlov, "Gesetz gegen die gemeingefährlichen Bestrebungen der Sozialdemokratie«. To attentatforsøg mod den aldrende kejser Wilhelm 1. havde fremkaldt den nødvendige politiske opbakning for rigskansler Bismarck til at gennemføre en undtagelseslovgivning mod det tyske socialdemokrati, der havde været i støt vækst i 1870'erne. Selv om det ikke kunne bevises, at partiet havde noget med de to attentater at gøre, gennemførtes nu en lov, der gav politimyndighederne tilladelse til at forbyde alle former for socialdemokratiske sammenslutninger, møder og tryksager. Der fastsattes hårde straffe for overtrædelser af loven. Retten til at opstille og blive valgt til rigsdagen blev imidlertid bevaret imod Bismarcks ønske, og den socialdemokratiske rigsdagsfraktion var nu den eneste legale ledelse af arbejderbevægelsen.

Socialdemokraterne var nu henvist til at opretholde den indbyrdes kontakt illegalt eller ved tilsyneladende selskabelige arrangementer. Dette blev også tilfældet i Slesvig-Holsten. Udbredelsen af forbudte tryksager fik også en væsentlig betydning for at holde sammen på bevægelsen. Fra september 1879 udgav partiet i Zürich ugebladet Der Sozialdemokrat. Organ der Sozialdemokratie deutscher Zunge. Bladet indsmugledes og udbredtes illegalt i hele Tyskland. En del blev således smuglet til Hamborg af søfolk, og herfra blev bladene sendt videre, f.eks. gemt under lokomotivernes kulvogne. Neumünster blev fordelingscentral for Slesvig-Holsten; men hårde fængselsstraffe truede fordelerne af forbudte tryksager. En af de hårdeste domme fik flensborgeren August Kückelhahn, der 1886 blev idømt 31/2 års fængsel i Altona. ${ }^{1}$ 
Manben med be tre $5 a a r$ og ben offenlige Denting.

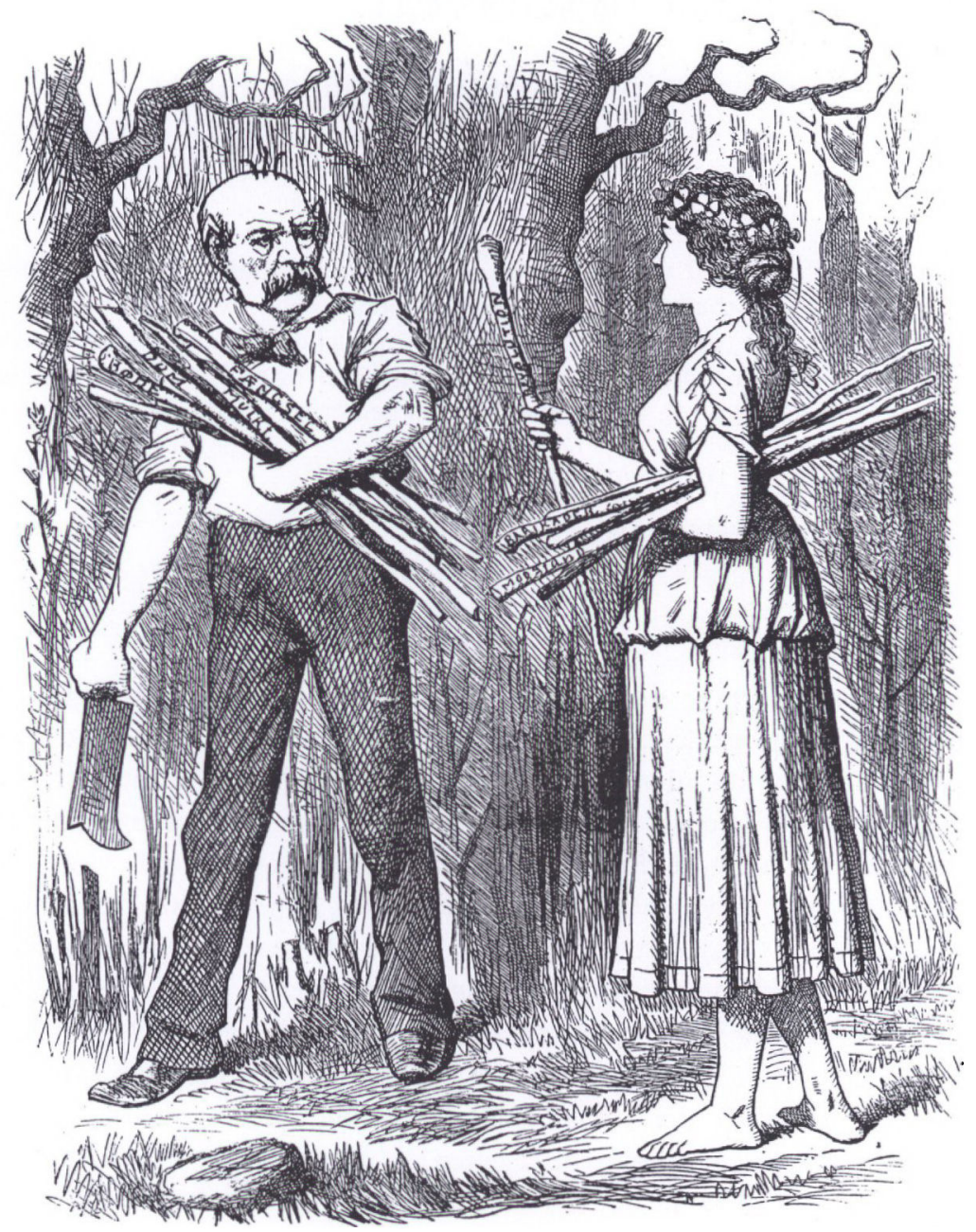

Tegning fra det danske, socialistiske satireblad Ravnen den 6. oktober 1878 med en kommentar til den forestående gennemforelse af Socialistloven. - Bismarcks forsag på at kvale socialdemokratiet med undtagelseslovgivning blev fulgt med megen opmarksomhed, ogsá uden for Tyskland. Teksten til tegningen her lyder:

Manden med de tre hår: $N \not d$, når nu Socialistloven er vedtaget, får jeg god brug for alle mine kappe til at muntre socialisterne med. Jeg skal min sjal banke oppositionen ud af dem.

Den offentlige mening: Nd, jeg vil nu ogsd fd brug for mine kappe, ndr Socialistloven bliver vedtaget, thi så får jeg lov til at banke ind $i$ din hjernekiste, at hverken undtagelseslove eller fangselsstraffe kan standse en stor idé. - Vogt dig, at der ikke engang bliver et ordsprog, der hedder: "Den trehärede gik så lange pd socialisterne, at han kom hovedlos hjem."

På Bismarcks kappe står: bode, dom, mulkt, fangsel, og pd̊ den offentlige menings: revolution, barrikader, modstand. 
Det var i Preussen, at Socialistloven håndhævedes med størst strenghed. I andre dele af riget lykkedes det derimod at grundlægge arbejderblade, i 1887 således Hamburger Echo og 1888 Die Nord-Wacht i Wilhelmshaven i Oldenburg. Die Nord-Wacht fik i Socialistlovens sidste år stor udbredelse i hele Nordvesttyskland og fik også sin betydning i Slesvig-Holsten.

Loven kom ikke til at opfylde sin hensigt: at få arbejderne til at vende sig fra socialdemokratiet. I 1880'erne iværksatte regeringen ellers en sociallovgivning i håb om derved at kunne knytte arbejderne stærkere til den bestående stat. Ganske vist faldt stemmetallene i 1881 til $6,1 \%$ af samtlige afgivne stemmer mod 7,6 i 1878, men ved de følgende valg var partiet i rask fremgang. I januar 1890 afviste rigsdagen at forlænge Socialistloven yderligere, når den udløb pr. 1. oktober 1890 , og ved rigsdagsvalget i februar 1890 opnåede socialdemokraterne $19,7 \%$ af de afgivne stemmer og var dermed rigets største enkeltparti.

I det følgende skal vi se på, hvordan denne udvikling forløb i de nordlige valgkredse i den slesvig-holstenske provins.

\section{Legale og illegale aktiviteter under Socialistloven}

Igennem 1870'erne havde der været udfoldet forskellig socialistisk aktivitet $\mathrm{i}$ det nordlige Slesvig, dog næsten udelukkende i købstæderne. I 1878 var aktiviteten på det nærmeste døet ud i Haderslev, Åbenrå, Sønderborg og Tønder. Flensborg havde som områdets største by den største arbejderbefolkning, og her havde arbejderbevægelsen bedre kunnet modstå det stigende pres fra myndigheder og arbejdsgivere. I 1878 fandtes således 6 fagforeninger, en politisk forening, Volks-Verein, en dannelsesforening, Bildungsverein, og en arbejdersangforening. ${ }^{2}$

Socialistloven blev håndhævet med stor strenghed i Slesvig-Holsten. I den nordlige del synes alle de eksisterende foreninger at være blevet opløst eller at have opløst sig selv. Kun en arbejdersyge- og begravelseskasse i Flensborg fra 1875 og bogtrykkerforeningen fik lov at leve videre. ${ }^{3}$

I hele perioden holdt politimyndighederne skarpt øje med folk, der var kendt som socialdemokrater eller mistænktes for at være det, og i Flensborg blev der flere gange foretaget husundersøgelser efter tryksager, der var blevet forbudt som følge af Socialistloven. I 1879 beslaglagdes således en større samling af både forbudte og tilladte skrifter i Flensborg, "for det lokale politi er for dumt til at vide, hvad der er forbudt og hvad ikke«, hedder det $i$ en korrespondance fra Flensborg til Sozialdemokrat. ${ }^{4}$

Politiske møder måtte som nævnt ikke afholdes. Først i 1884 vedtog rigsdagen, at socialdemokraterne kunne holde valgmøder før rigsdagsvalgene. Allige- 
vel forbød Flensborgpolitiet to socialdemokratiske valgmøder. Dette blev skyld i, at rigsdagen erklærede valget i Flensborg-Åbenråkredsen for ugyldigt, således at der måtte holdes nyvalg i kredsen i 1886.

Forfølgelserne medførte frafald i rækkerne. Her kan f.eks. nævnes cigarmager Fr. Döll fra Flensborg. Ved et suppleringsvalg til rigsdagen i 1879 optrådte han på valgmøder, hvor han anbefalede at stemme på den tyske nationalliberale kandidat og erklærede, at han ikke længere var socialist. ${ }^{5}$ Sammen med Döll optrådte også på et valgmøde i Åbenrå udgiveren af den tyske borgerlige avis Apenrader Zeitung, Josef Böheim. Han havde været en fremtrædende socialist i Kiel, men var i 1878 blevet ansat i Åbenrå som typograf hos bogtrykker Matzen, der fra 1879 var udgiver af den danske avis Hejmdal. Matzen skrev senere om Böheim, at han ved ansættelsen af ham havde tænkt, "at hans sindelag nok skulle blive anderledes, når han kom her til Åbenrå, da vi jo ikke havde mange socialister, som han kunne pleje omgang med. Hvo, der dengang havde set den ivrige socialdemokrat, der var familiær med enhver simpel arbejdsmand, ville næppe kunne genkende denne i den nu så højnæsede "redaktør«, der drejer knappen efter vinden. ${ }^{6}$

I Flensborg bevarede arbejderbevægelsen kontinuiteten fra 1870'erne. Lederen var som i slutningen af 1870 'erne skrædder Heinrich Mahlke, der var kommet til Flensborg i 1874 fra Hamborg. Fra 1903-07 repræsenterede han den 2. slesvig-holstenske rigsdagsvalgkreds (Flensborg-Åbenrå) i rigsdagen. Det var den eneste gang før 1914 , at der blev valgt en socialdemokrat her. ${ }^{7}$

Sløjere stod det til i Nordslesvig. Kun fra Åbenrå kendes en socialdemokrat, der var aktiv både i 1870'erne og efter Socialistlovens ophævelse, nemlig skomager Hugo Gladewitz. Han var tilflyttet sydfra som så mange andre af arbejderbevægelsens pionerer i landsdelen. ${ }^{8}$ Indfødt var derimod tobaksspinder Jørgen Christensen, der var født i Åbenrå. Han blev 1887 i Danzig idømt 14 dages fængsel for deltagelse $i$ en hemmelig, socialistisk sammenslutning. Derefter vendte han tilbage til Åbenrå, hvor han fik arbejde i J.P.Junggreens tobaksfabrik. Fra 1888 stod han for fordelingen af Die Nord-Wacht til 40-50 abonnenter. ${ }^{9}$ Helt frem til 1920 var Christensen en af partiets førende mænd i Åbenrå.

I slutningen af Socialistlovens periode kan man igen spore nogen socialdemokratisk aktivitet uden for Flensborg. Det fremgår dels af stemmetallene, der skal behandles senere, dels af at der fra 1888-89 blev sendt korrespondancer til Nord-Wacht fra Haderslev, Åbenrå og Tønder. ${ }^{10}$ Men det ændrer ikke noget ved, at den flensborgske arbejderbevægelse var helt dominerende i området $\mathrm{i}$ perioden. Valgagitationen organiseredes herfra, og også illegalt forsøgte man at udbrede arbejderbevægelsens synspunkter.

Den første uddeling af illegale flyveblade fandt sted i Flensborg i pinsen 


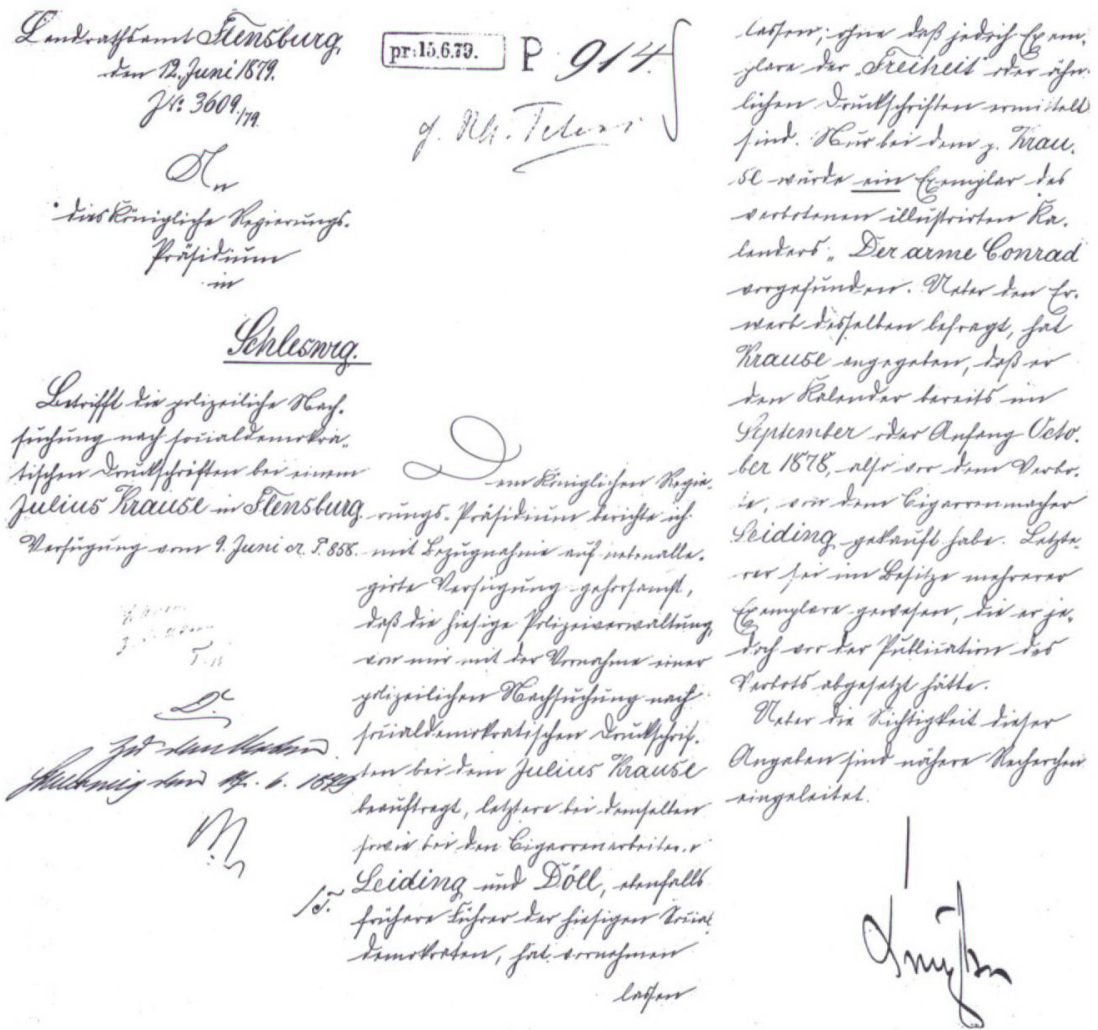

Politirapport om en husundersagelse efter forbudte tryksager i Flensborg 1879. Hovedkilden til arbejderbevagelsens historie $i$ Flensborg og Nordslesvig under socialistloven er foruden pressestoffet politiets registreringer og indberetninger til regeringsprasidenten $i$ Slesvig. Foreningsarkiver, personlige papirer o.lign. synes ikke bevaret, og det ger det vanskeligt at fd et dyberegående indtryk af de implicerede personer, intern debat osv.

Politirapporten, der gengives som en prove pd det eksisterende kildemateriale, fortaller, at husundersagelsen var resultatles hos de to tidligere socialister, cigarmagerne Fr. Döll og Thomas Leiding. Derimod var der fundet ét eksemplar af en forbudt illustreret kalender «Der arme Conrad" hos typograf Julius Krause, der hevdede at have erhvervet den for Socialistlovens vedtagelse. Krause, der var typograf ved Flensburger Nachrichten, havde varet en af lederne for Flensborgsocialdemokraterne i 1870'erne, og han blev 1893 forretningsforer ved det nye partiblad Schleswig-Holsteinische Volks-Zeitung $i$ Kiel. (Landesarchiv Schleswig-Holstein Abt. 309 nr. 12550.)

1881, hvor socialisterne havde spredt ca. 700 eksemplarer illegale pjecer i det populære udflugtssted Frueskoven. " - Fra 1888 kan nævnes en større uddeling af flyveblade med titlen "An die Bevölkerung Flensburgs«. Bladet indeholdt stærke angreb på undertrykkelsen af partiet, en opfordring til at stemme socialdemokratisk ved næste valg og desuden til at lade flyvebladet gå fra 
hånd til hånd. Opråbene fordeltes i lukkede kuverter med den opfindsomme trykte afsenderbetegnelse »Heim für gefallene Mädchen, Flensburg" (Hjem for faldne kvinder). ${ }^{12}$ Endelig kan nævnes, at Flensborgsocialdemokraterne på 10-årsdagen for Socialistlovens indførelse havde held til at hejse røde faner tre forskellige steder $\mathrm{i}$ byen og opklæbe et større antal røde sedler med datoen den 21 . oktober 1878 , lovens ikrafttredelsesdato. ${ }^{13}$

Imidlertid er omfanget af de illegale aktiviteter ifølge sagens natur nappe kendt $\mathrm{i}$ deres fulde omfang. Bedre kendt er de vigtige aktiviteter, der legalt kunne foregå i sygekasserne og i fagbevægelsen, og som på længere sigt fik betydning ved at gøre arbejderne mere modtagelige også for den politiske virksomhed. I det følgende skal denne udvikling kort skitseres.

\section{Organisatorisk udvikling}

Sygekasser

Som et led i Bismarcks socialreformer indførtes 1883 sygeforsikringstvang for alle arbejdere med en årsindtægt på under 2000 mark. Selv om arbejderne blev sikret en væsentlig indflydelse på forvaltningen af de nye sygekasser, foretrak de under Socialistloven i stort omfang at organisere sig i deres egne frie kasser, der fortsat var lovlige som en alternativ forsikringsmulighed. Bismarcks sociale reformer blev nemlig betragtet som et taktisk middel til at skille arbejderne fra socialdemokratiet, således som det bl.a. blev fastslået i en resolution fra partiets kongres i København 1883.

I de nordslesvigske købstæder ser det ikke ud til, at arbejderne i noget betydeligt omfang udviklede deres egne sygekasser. Det modsatte var tilfældet

In Folye einiger gerinafügiger Deis nungติäuẑerungen in Der Beriammluna bom 29. Decbr. v. $\mathfrak{J}$. in "Eoloffeum" wuroe ich von der Beritoirection entlailen uno babe ich mich genöthigt gefeben, meinen Lebenwunterbalt ourch eine

\section{$\mathfrak{Y a f e r e i}$}

\u berdienen und bitte ich des̄balb freunde uno Befannte, mich in meinem Unter= nebmen zu unterftüben.

Durd Eingabe von Urorīen Iaīe id bei Den Betreffenden borfragen und liefere ich थlles frei in $\dot{b} a u s$.

(3). Etüifel,

tar $x$ is leeteg 5 .
I arbejderbevagelsens pionertid kunne det koste dyrt at vare politisk aktiv. Det viser f.eks. denne annonce, hvor socialdemokraten G. Stöckel oplyser, at han er blevet afskediget af varftsdirektionen for udtalelser, han har fremsat pd et borgerligt mode. Derfor har han nu ábnet en hokerforretning. Det var ikke ualmindeligt, at socialdemokrater matte forsege at etablere sig som selvstandige, när ingen arbejdsgiver ville ansatte dem. (Flensburger Annoncenblatt 12. februar 1885, $i$ Flensborg Avis' arkiv pk. 3. Dansk Centralbibliotek for Sydslesvig) 
i Flensborg. Her er det også tydeligt, at arbejdet i de frie hjælpekasser i høj grad blev ledet af socialdemokrater. Kasserne omfattede enkeltfag, og der fandtes oftest rigsomfattende forbund af dem. På denne måde blev de et vigtigt bindeled mellem socialdemokraterne.

\section{Fagbevagelsen}

De legale arbejderorganisationer, der fik størst betydning i perioden, var imidlertid fagforeningerne. Efter vedtagelsen af Socialistloven var de fleste fagforbund blevet opløst, da myndighederne mente, de var under socialdemokratisk indflydelse; men fagbevægelsen blev efterhånden reorganiseret. I Flensborg kom der især gang i organiseringen $i$ årene efter 1885 , således at der ved Socialistlovens ophør fandtes i hvert fald 23 fagforeninger i byen, omfattende alle centrale fag. Foreningerne var erklæret upolitiske og skulle kun varetage arbejdernes økonomiske interesser. Politiske spørgsmål måtte ikke diskuteres på møderne.

I Nordslesvig skete spredte organisationsforsøg i periodens senere år i alle de fire købstæder. I Haderslev fandtes 1890 en lokalafdeling af skomagerhjælpesygekassen og en murerfagforening. ${ }^{14}$ En tobaksspinderforening eksisterede 1887-90. Endelig stiftedes en afdeling af tømrerforbundet i $1890 .^{15}$

I Åbenrå dannedes 1890 fagforeninger for murere og havnearbejdere, og der fandtes foreninger for skræddere og skomagere. Formentlig var også tobaksarbejderne organiserede. ${ }^{16}$ I Sønderborg oprettedes i maj 1890 en lokalafdeling af skrædderforbundet, og i Tønder oprettedes 1889 en fagforening for murere og tømrere, der opløstes igen $1890 .{ }^{17}$

Den svage industrialiseringsgrad i Nordslesvig er vel hovedårsagen til, at fagbevægelsen var så lidt udviklet i forhold til Flensborg. Men at de sproglige forhold i Nordslesvig også lagde den tyske fagbevagelse hindringer i vejen, fremførtes af Haderslevs repræsentant på den tyske murerkongres i 1890. Han beklagede sig over, at de dansktalende landmurere optrådte som løntrykkere; men man kunne ikke bevæge dem til at indtræde i fagforeningen, idet de undskyldte sig med, at de ikke forstod det tyske. ${ }^{18}$ Dette sproglige problem havde fagbevægelsen i Flensborg ikke. Således skal murerfagforeningen allerede kort efter sin oprettelse have haft et antal medlemmer fra de omkringliggende småbyer. ${ }^{19}$

\section{Arbejdskonflikter}

Strejkeaktiviteten i Tyskland som helhed var stigende i løbet af 1880 'erne og kulminerede $\mathrm{i}$ årene 1889-91. Også i det nordlige Slesvig var arbejderne fagligt i offensiven i Socialistlovens sidste år; kun fra Tønder kreds findes ingen vidnesbyrd herom. Arbejdernes krav var højere løn, kortere arbejdstid og 


\section{Mitarbeiter!}

Heute Abend soll, wie Ihr wisst, die Werfe geschloszen werund wir Alle sollten hungern. Man will uns gegen die Former aufhetzen urd zu Ruhestörungen veranlaseen. was für uns die grössten Nachtheile zum Gaudium unserer Austoutherbei cühren würdc

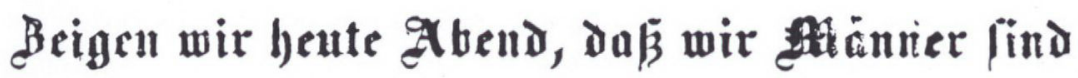

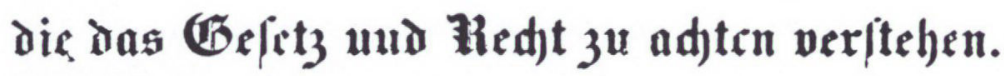

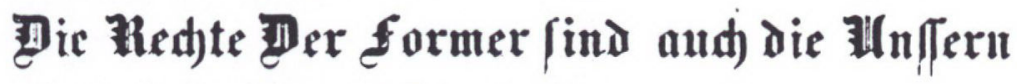

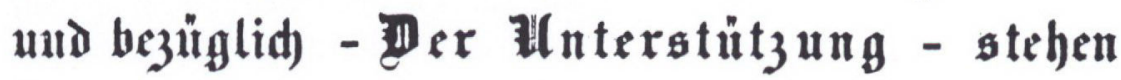

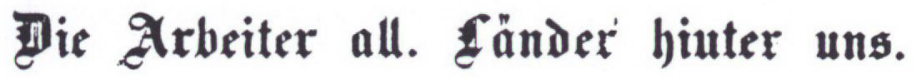

\section{Eure Kollegen.}

Lobeseddel $i$ anledning af lock-out-erklaringen fra varfisledelsen $i$ Flensborg december 1888. Lobesedlen, som politiet mente var forfattet af G.Stöckel (jf. illustration s. 356), opfordrer til at undgå uroligheder: "Lad os vise $i$ aften, at vi er mand, der forstar at agte lov og ret." Sterstedelen af den tyske arbejderbevagelse onskede under socialistloven at fore en kurs, der ikke ville give regeringen påskud til skarpelse af undtagelseslovgivningen. (Landesarchiv Schleswig-Holstein Abt. 309 nr. 219)

anerkendelse af organisationsretten; men det var især på de første to områder, der opnåedes resultater. Således ser det ud til, at kravet om en 10-timers arbejdsdag $\mathrm{i}$ vidt omfang blev imødekommet $\mathrm{i}$ årene 1889-90.

Indrømmelserne fra arbejdsgiverne kunne undertiden opnås uden konflikt; men særlig i Flensborg kom det til flere forbitrede arbejdskampe i sidste halvdel af $1880^{\prime}$ erne. Den mest omfattende konflikt var en lock-out af ca. 900 arbejdere på værftet $\mathrm{i}$ december 1888. Det var en formerstrejke, der blev besvaret på denne måde af værftets direktion. Lock-outen blev hurtigt afblæst, mens formerstrejken varede til ind i februar, efter at værftet forgæves havde forsøgt at skaffe skruebrækkere til at udføre arbejdet. Da konflikten var 
Unterstuitzungs-Verein Deutscher Buchdrucker.

„Flerisborg Avis' « Bogtrykkeri (Jessen) i Flensborg er blokeret, hvorfor al Tilgang til Flensborg frabedes.

Chr. Heismann, Kredsformand.

Meddelelse i det danske typograffagblad om blokade mod Flensborg Avis' trykkeri 1889, et eksempel på det internationale samarbejde, der praktiseredes i fagbevagelsen. At meddelelsen ikke var uberettiget ud fra fagforbundets synspunkt viste sig, da Flensborg Avis kort tid efter annoncerede efter "En duelig satter, der ikke er medlem af nogen fagforening ..." (Typograf-Tidende 15. marts 1889)

ophørt, indrømmede værftet samtlige arbejdere en lønforbedring og indførelsen af 10-timers arbejdsdagen. ${ }^{20}$ Det er ikke tanken her at gå i detaljer med den faglige udvikling; men en typografkonflikt på Flensborg Avis kan have interesse fra et dansk synspunkt.

Typografernes uoverensstemmelser med redaktør J. Jessen var begyndt $i$ 1886, da hele personalet i trykkeriet på faktoren nær rejste krav om betaling efter en ny fagforeningstarif. Jessen sad på dette tidspunkt $\mathrm{i}$ fængsel for fornærmelser mod Bismarck, og den tilbageværende ledelse bevilgede lønforhøjelsen. Da Jessen kom tilbage i 1887, udtalte han, at han anså sig for løst for enhver moralsk forpligtelse over for personalet, og at han $i$ givet tilfælde ikke ville betænke sig på at antage et andet personale. I 1889 blev maskinmesteren afskediget med begrundelse i forskellige uregelmæssigheder og umedgørlighed. Typografernes opfattelse var, at Jessen ville slagte dem enkeltvis og desuden spare løn, for den nye, uorganiserede maskinmester fra Danmark fik nemlig en lavere løn end den gamle. Desuden var en sætter blevet truet med afskedigelse, da han på tysk havde nynnet for sig selv "Nur am Rhein da will ich leben«, og havde været i skænderi med faktoren. I protest mod den nye maskinmester forlod de otte typografer trykkeriet.

En kort tid klarede avisen sig så med sættere fra Hamborg. Det var besværligt med sættere, der ikke kunne dansk, og desuden overtalte fagforeningen dem efterhånden på nær én til at rejse. Også den danske maskinmester rejste, da han i det danske typografblad var blevet hængt ud som skruebrakker; men takket være stor arbejdsløshed blandt typograferne i Haderslev blev de ledige stillinger besat. Det var ved den anledning, den senere kendte dansksindede socialdemokrat og politimester i Flensborg i overgangstiden, Waldemar Sørensen, kom til avisen, hvor han arbejdede til 1905. - Konflikten endte altså med et nederlag for fagforeningen. Senere tillod Jessen dog sætterne at melde sig ind $\mathrm{i}$ fagforeningen og betalte også efter tariffen, selv om han ikke ville have nogen overenskomst med foreningen.

Jessens holdning til fagforeningen var typisk for mange arbejdsgivere på 
denne tid, danske som tyske; men konflikten synes at have skadet hans forhold til den flensborgske arbejderbevægelse, så vidt man kan dømme ud fra dens korrespondancer til Nord-Wacht, der indeholder flere bitre angreb på ham. Flere år efter, i 1892, mindede en korrespondance om konflikten i 1889. Den betegnede Flensborg Avis' trykkeri som en rigtig "Schusterbude«, et typografudtryk for et dårligt trykkeri, som man mente især blev drevet ved lærlingeudbytning. ${ }^{21}$

I et følgende afsnit vil der blive lejlighed til at redegøre nærmere for redaktør Jessens forhold til den politiske side af arbejderbevægelsen.

\section{Valgagitation}

Under Socialistloven var det særlig vigtigt for socialdemokratiet at blive repræsenteret i rigsdagen, det eneste forum, hvor arbejderbevægelsen fuldt legalt kunne propagandere for sine idèer, ofte under stor offentlig opmærksomhed. Valgagitationen var derfor en meget vigtig side af det organisatoriske arbejde, og for det nordlige Slesvigs vedkommende udgik initiativet fra Flensborg.

I Flensborg var partiet som omtalt afskåret fra at holde sine egne valgmøder før valgene i 1879, 1881 og 1884; men ved de følgende valg blev der holdt møder både i byen og enkelte steder i oplandet. Problemet for mødeafholdelsen var at finde værter, der turde og ville stille lokaler til rådighed. I Åbenrå måtte planlagte møder i 1886 og 1889 opgives af den grund, og heller ikke 1890 synes der at have været noget valgmøde. Men i både Haderslev og Tønder holdtes møder med rigsdagskandidaterne i 1890 . $\mathrm{Nu}$ var arbejderbevægelsen i Flensborg også blevet så stærk, at den med succes kunne lægge pres på en lokalevært. Man ønskede »Sängerhalle« i Tivoli til møderne; men forvalteren dér havde erklæret over for arbejdervalgkomiteen, at han for at undgå at lægge sig ud med nogen overhovedet ikke ville overlade lokalet til noget politisk parti. Desuden skulle militæret have truet ham med boykot, hvis han gav tilladelse til socialdemokratiske møder. Men da han især levede af sine arbejderkunder, ville socialdemokratiet opfordre alle arbejdere og deres sympatisører i byen til at boykotte etablissementet. Også på en række fagforeningsmøder erklæredes boykotten, og værten kapitulerede hurtigt. Politimesteren måtte med beklagelse konstatere: "Hele sagen viser på ny partiets fortræffelige disciplin og deres føreres faretruende magt. ${ }^{22}$

Af stigende omfang blev i periodens løb den agitation, der skete ved uddeling af flyveblade og stemmesedler med den socialdemokratiske kandidats navn. Dette sidste var så vigtigt, fordi stemmesedler blev fremstillet og fordelt af de enkelte partier. De steder, hvor socialdemokratiet ikke fik uddelt sine stemmesedler, blev der følgelig heller ikke afgivet socialdemokratiske stemmer.

Ved valget 1884 organiserede Flensborgsocialdemokraterne for første gang 
under Socialistloven uddeling af stemmesedler i Åbenrå. ${ }^{23}$ Et forbudt flyveblad uddeltes i Flensborg i ly af nattemørket, og 125 eksemplarer blev sendt med posten til forskellige af byens indbyggere. ${ }^{24}$ I 1886 uddelte man gummierede sedler med kandidatens navn til påklistring på døre, mure, træer, plankeværker, trappegange og rygge på folk. ${ }^{25}$ Fra rigsdagsvalget 1886 begyndte landagitationen at få et stigende omfang i 2 . kreds, og i 1887 uddeltes desuden stemmesedler og valgopråb i Haderslev by.

Periodens valgagitation kulminerede ved rigsdagsvalget 1890 , hvor der $\mathrm{i}$ Åbenråkredsen også agiteredes på landet. Det samme skete i mindre omfang i 1. kreds. For første gang havde valgkomiteen i Flensborg fremstillet et tosproget valgopråb til brug i de dansktalende områder, og for første gang under Socialistloven agiterede Flensborg-socialdemokraterne i Sønderborg ved fordeling af flyveblade. ${ }^{26}$

Den flittige organisatoriske og agitatoriske indsats blev fulgt af en politisk fremgang ved valgene. Det politiske arbejde i det nordlige Slesvig fik sit særpræg på grund af modsætningen mellem dansk og tysk. Lige siden 1872 havde socialisterne ved et suppleringsvalg i 2 . kreds appelleret til de dansksindede arbejdere om at stemme socialdemokratisk. Særlig for den nationale udvikling i Flensborg blev arbejderbevægelsens fremvækst af betydning, og derfor vil forholdet til den danske bevægelse og dennes reaktioner blive behandlet ret udførligt i det følgende.

\section{Politisk udvikling og forholdet mellem socialdemokratiet og den danske bevægelse}

\section{Nogle hovedtrak}

Ligesom i det tyske rige som helhed gik socialdemokratiet i Slesvig-Holsten politisk styrket ud af perioden med socialistloven. Ved valget i 1881 var stemmeandelen faldet til $11,2 \%$ af de afgivne stemmer i provinsen; men ved de følgende valg steg socialdemokraternes stemmetal stærkt, således at det $\mathrm{i}$ 1890 nåede op på 32,2\%, altså væsentligt over rigsgennemsnittet på 19,7\%. Hermed var socialdemokratiet blevet det største parti i Slesvig-Holsten, og partiets hidtil bedste valgresultat fra 1874 på $31,8 \%$ af de afgivne stemmer var nu overgået. Af provinsens 10 valgkredse var de to erobret ligesom i 1874 . Fra 1884 valgtes Karl Frohme i 8. kreds, Altona-Stormarn, og i 1890 valgtes desuden Hermann Molkenbuhr i 6. kreds, Pinneberg-Segeberg. ${ }^{27}$

Mens den politiske udvikling i provinsen i 1870'erne havde tydet på en voksende accept af indlemmelsen og forholdene i Preussen, skete der allerede ved valget 1881 et nyt omsving $\mathrm{i}$ oppositionel retning, idet de borgerlige 


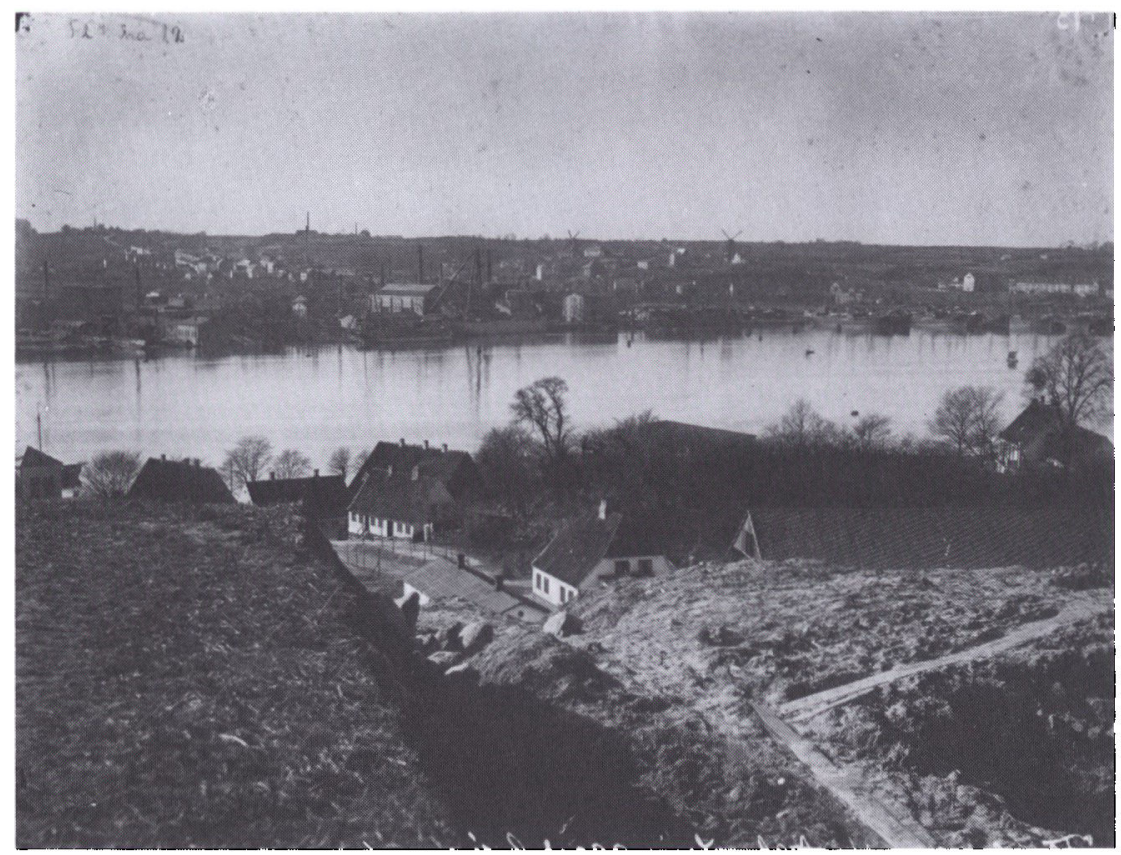

Udsigt over Flensborg med varftet, byens storste arbejdsplads $i$ baggrunden til venstre. Foto i Dansk Centralbibliotek for Sydslesvig.

oppositionspartier, fremskridtspartiet og den liberale forening, erobrede 7 af provinsens valgkredse. Denne tendens gjorde sig også gældende i Tyskland som helhed, således at regeringspartierne mistede flertallet $i$ rigsdagen. Men $i$ 1887 vandt regeringspartierne, de nationalliberale og konservative, $i$ et forbund under navnet kartelpartierne, flertallet tilbage. Den borgerlige opposition i Slesvig-Holsten, fra 1884 forenet i det tyskfrisindede parti, holdt sig imidlertid bedre. I 1890 havde de 5 af provinsens rigsdagsmandater, men regeringspartierne fik 2 , socialdemokraterne 2 og de dansksindede 1.

Et udslag af den oppositionelle indstilling i provinsen Slesvig-Holsten var det formentlig også, at den danske kandidat i 2. kreds, Gustav Johannsen overraskende blev valgt ved omvalget (2. valgomgang, der afholdtes, hvis ingen af kandidaterne $i$ kredsen opnåede absolut flertal ved hovedvalget) $i$ 1881, efter at han i valgkampen bl.a. havde protesteret mod regeringens upopulære økonomiske politik (se senere). Denne valgsucces, der næppe kan tolkes snævert som en nationalt betinget reaktion, ændrede ikke den kendsgerning, at danskheden $\mathrm{i}$ det nordlige Slesvig som helhed var i tilbagegang $\mathrm{i}$ 
1880'erne. Særlig udpræget blev denne udvikling i Flensborg, hvor det danske parti med 590 stemmer var reduceret til politisk ubetydelighed i 1890 , mens socialdemokratiet var blevet byens største parti og for første gang fik sin kandidat på omvalg. I Aksel Lassens bog: Valg mellem tysk og dansk (1976) er stemmetallene analyseret med henblik på at belyse de nationale forskydninger, der derfor ikke skal omtales nærmere her.

I de tre nordlige valgkredse var det kun i 2 . kreds, at socialdemokratiet kunne hævde sig under Socialistloven. 1. kreds (Haderslev-Sønderborg) og 4. kreds (Tønder-Husum-Ejdersted) var provinsens svageste i denne periode.

\section{Samarbejde $i$ den tyske rigsdag}

I 1870'erne havde den enlige danske rigsdagsmand H.A.Krüger fortrinsvis støttet sig til repræsentanterne for det katolske oppositionsparti Centrum, foruden de andre undertrykte nationaliteter polakkerne og elsass-lothringerne. I 1880'erne havde Centrum imidlertid opgivet sin krasse opposition imod Bismarck, og efter valget 1881, hvor både Gustav Johannsen og Hans Lassen (i 1. kreds) var blevet valgt til rigsdagen, skiftede de danske rigsdagsmænd taktik. Hos de tyske partier søgte de nu fortrinsvis støtte hos det nye frisindede oppositionsparti, fremskridtspartiet. Det lykkedes især godt for Gustav Johannsen, der knyttede personlige venskaber med flere af de frisindede politikere og endog deltog $i$ den frisindede rigsdagsfraktions møder i sin første valgperiode 1881-84. Efterhånden fik Johannsen også nærmere forbindelse med førerne for det stadigt voksende socialdemokrati. ${ }^{28}$

Ligesom de andre oppositionspartier støttede socialdemokraterne de danske rigsdagsmænd ved afstemningerne. J.P.Junggreen, rigsdagsmand for 1. kreds 1884-86, stod både de frisindede og især socialdemokratiet fjernt i politisk henseende; men han anerkendte deres støtte, da han $1886 \mathrm{skrev} i$ et privat brev om forholdene på rigsdagen: „Flertallet er hovmodigt og blændet af rigets storhed og magt, der efter dets mening tillader, at man sætter sig ud over alle hensyn, og et mindretal, der måske dog ikke ganske billiger, hvad der sker, har ikke courage til at vedkende sig dette. De bliver jo så straks henregnet til landsforræderne og rigsfjenderne. De eneste tyskere, der ved afstemninger ærligt har vedkendt sig deres mening om, at der er og bliver gjort uret imod os, er socialisterne. ${ }^{29}$

Den socialdemokratiske leder W.Liebknecht havde således taget ordet den 28. januar 1885, da Junggreens andragende om forvaltnings- og retssproget $i$ Nordslesvig var til forhandling i rigsdagen. Liebknecht erklærede sig i princippet enig i Junggreens kritik. Ganske vist mente han ikke, at det tyske element i Nordslesvig skulle undertrykkes af det danske; men man måtte holde på, at medlemmer af fremmede nationaliteter, der tilhørte det tyske rige, skulle have 
deres ret $\mathrm{i}$ alle henseender, for hvorledes kunne man ellers forlange, at det tyske sprog skulle skånes $i$ andre lande? ${ }^{30}$

Dette var i overensstemmelse med det tyske socialdemokratis kritiske holdning $i$ almindelighed over for den administrative og kulturelle undertrykkelse af de forskellige ikke-tyske nationaliteter i riget. Et slags skæbnefællesskab som "rigsfjender" kunne på nogle punkter forene socialdemokrater og repræsentater for nationale minoriteter, der ikke hyldede socialistiske ideer.

Men hvorledes stillede det tyske socialdemokrati sig til spørgsmålet om national selvbestemmelse, hjertesagen for de dansksindede sønderjyder, også efter at ophævelsen af $\S 5$ (løfteparagraffen i Pragfreden 1866 om iværksættelse af en folkeafstemning i det nordlige Slesvig om det nationale tilhørsforhold), var blevet kendt i 1879 ?

\section{Socialdemokratiet og det nordslesvigske sporgsmål}

I 1870'erne var de tyske socialdemokrater flere gange gået ind for praktiseringen af den nationale selvbestemmelsesret, også i det nordslesvigske spørgsmål. Men i 1880 'erne synes partiets politikere at have mistet interessen for det oprindelige krav om en folkeafstemning. Såvidt vides, har de ledende rigsdagsmænd Aug. Bebel og W. Liebknecht ikke i 1880'erne udtalt sig om spørgsmålet; men andre politikere gjorde det ved møder i landsdelen i 1880'erne.

Ved rigsdagsvalgene 1884,1886 og 1887 i 2 . kreds var den socialdemokratiske kandidat en af Slesvig-Holstens førende socialdemokrater, nemlig den østrigsk fødte skrædder Stephan Heinzel, der havde arbejdet i Kiel siden $1869 .{ }^{31}$ På et valgmøde i Flensborg den 27. marts 1886 udtalte Heinzel ifølge Flensborg Avis' referat, at "han troede, at der ingen udsigter var til, at Slesvig ville komme tilbage til Danmark. Paragraf 5 var ophævet, og hvis Slesvig skulle komme tilbage til Danmark, måtte det ske ved en stor omvæltning i Europa. Tyskland kunne heller ikke afstå Nordslesvig, eftersom den nuværende grænse passede så godt. Slesvigs geografiske og territoriale beliggenhed måtte være bestemmende for, hvem landet skulle tilhøre. $\aleph^{32}$ Ved et møde i Harreslev udtrykte Heinzel mere malerisk det samme: »Det var sket én gang, at hvalfisken udspyede Jonas; men det ville næppe ske anden gang. ( $^{33}$ Ved et møde $\mathrm{i}$ Flensborg den 4. februar 1887, hvor Liebknecht egentlig skulle have talt, udtalte redaktør Hermann Förster, Hamborg, sig i samme retning. Danskerne glemte, at der hørte magt til at hævde traktaterne; derfor var det frugtesløst at håbe noget af dem. ${ }^{34}$ Også Mahlke, der blev kredsens rigsdagskandidat $\mathrm{i}$ 1890, udtalte på mødet i Harreslev 1886, „»... at da $\S 5$ i Pragfreden var ophævet, var der ingen udsigt til, at Nordslesvig kom tilbage til Danmark ... $\ll^{35}$, og hans valgopråb fra 1890 betegnede spørgsmålet om en grænseændring som ligegyldigt. 
Så vidt man kan slutte på grundlag af disse meget få udsagn, var der $\mathrm{i}$ det slesvig-holstenske socialdemokrati en tilbøjelighed til at acceptere status quo i det slesvigske spørgsmål (en udvikling, der i øvrigt også kendetegner det tyske socialdemokratis holdning i det elsass-lothringske spørgsmål). Det skyldes ikke, at man nu billigede Preussens anneksion af landsdelen, men snarere at man anså muligheden for at indfri $\S 5$ for utopisk. Desuden førtes agitationen i perioden bl.a. for at vinde hidtil dansksindede arbejdere. Den danske bevægelses politiske udsigter tegnede sig mørkt, og de sociale modsætninger skærpedes under industrialiseringsprocessen. Derfor var det logisk at vælge en taktik, der advarede arbejderne mod at knytte nogen som helst forhåbning om bedre sociale forhold sammen med urealistiske forventninger om indfrielsen af $\S 5$. $\mathrm{Nu}$ henvistes udelukkende til, at arbejderne måtte forene sig efter deres klasseinteresser. Dette havde også været hovedpunkt i 1870 'ernes agitation; men samtidig var socialisternes positive holdning til princippet om den nationale selvbestemmelsesret blevet fremhævet. Først efter 1890, da partiet begyndte at agitere kraftigere i Nordslesvig, og det var blevet klart, at det nationale spørgsmål fortsat var centralt $\mathrm{i}$ det politiske liv her, blev spørgsmålet om selvbestemmelsesretten igen et vigtigt element i partiets agitation. ${ }^{36}$

I de lokale valgkampe 1881-90 kritiserede socialdemokraterne ikke tvangspolitikken over for de dansksindede. Agitationen kendetegnedes tværtimod af bitter rivalisering, og det socialdemokratiske syn på den danske bevægelse formuleredes f.eks. i Mahlkes danske valgopråb 1890: „Det danske parti, som foreslår Eder hr. Gustav Johannsen fra Flensborg, forfølger aldeles forkerte mål, lad dem mene det nok så godt. De synes ikke at have andre idealer end at komme ind under den danske regering. Bliver der da ikke i Danmark ført det samme regiment som hos os? Jo vist! I dag er partiet oppositionel lige over for den tyske Regierung, men når vi kom ind under Danmark, så ville det som konservativt parti gå igennem tykt og tyndt med Estrup, lige som det tyske parti gør det med fyrst Bismarck. Det danske parti skulle i første linje søge at virke derhen, at det blev bedre i Tyskland, så at alle kunne bo sammen som brødre og glæde sig over tilværelsen. Men da partiet ikke gør det, må dets kandidat ikke blive vor talsmand i denne kreds. $\aleph^{37}$

\section{Gustav Johannsens agitation 1881-90}

Socialdemokraternes iver for at fastslå, at de dansksindede stod for en politisk konservatisme, kan delvis have sin baggrund i Gustav Johannsens bestræbelser for at give sine valgprogrammer et konkret politisk indhold af frisindet karakter.

Gustav Johannsen var 1869-82 redaktør af Flensborg Avis og havde både heri og på møder argumenteret for, at de dansksindede arbejdere skulle blive 
ved at stemme dansk ved valgene. Han var 1881-84 rigsdagsmand for Flensborg-Åbenråkredsen og fra 1886-1901 for Haderslev-Sønderborgkredsen. Hans anseelse og popularitet blandt høj og lav og også blandt politiske modstandere var betydelig.

Ved valget 1881 kandiderede Johannsen for første gang til rigsdagen. Før hovedvalget offentliggjorde han et valgprogram, der var et brud med det danske partis hidtidige, rent nationale agitation. Den umiddelbare foranledning synes at have været en bekendtgørelse fra "flere vælgere« $i$ Flensburger Annoncenblatt, hvor der opfordredes til at stemme på den socialdemokratiske kandidat W. Hasenclever. Som motivering blev angivet, at både den konservative og den nationalliberale kandidat ville stemme for nye skatter respektive indirekte skatter på levnedsmidler. ${ }^{38}$ Denne økonomiske politik ville ramme de dårligststillede hårdest. På et vælgermøde i Flensborg den 22. oktober 1881 udtalte Gustav Johannsen sig nu stærkt imod den bismarckske indenrigspolitik, imod de indirekte skatter efter det preussiske system, for en fastere ordning af håndværksvæsenet, imod tugthusarbejdet etc., altsammen emner der diskuteredes i den almindelige tyske valgkamp. ${ }^{39}$ I fortsættelse heraf offentliggjorde Johannsen et valgopråb i Flensborg Avis den 26. oktober: "Til "flere vælgere««, altså formentlig med adresse til det socialdemokratiske opråb $\mathrm{i}$ annoncebladet. Han beklagede $\mathrm{i}$ opråbet, at han ikke kunne holde endnu et valgmøde $\mathrm{i}$ Flensborg; men han ville svare således på de spørgsmål, der var stillet til ham. Han var "modstander af tobaksmonopolet«, "principiel modstander af undtagelseslove« (som Socialistloven), og desuden ville han "stemme for en på sunde og holdbare grundprincipper baseret lov om forsikring for ulykkestilfælde«, et hovedspørgsmål i valgkampen 1881. Endelig fremhævedes, at han også ville deltage $\mathrm{i}$ et eventuelt omvalg.

Også dette var et brud med den afdøde rigsdagsmand H.A.Krügers taktik. Krüger havde opstillet som dansk kandidat i både 1., 2. og 4. kreds. Han betragtede resultatet ved hovedvalget som en slags folkeafstemning om det nationale tilhørsforhold og deltog som følge heraf ikke i de forskellige omvalg i 2. og 4. kreds (i 1. kreds fik han stemmer nok til at blive valgt ved hovedvalget). Denne taktik havde utvivlsomt svækket den danske valgdeltagelse i de to sydlige valgkredse, fordi man vidste, at Krügers valg i forvejen var sikkert.

Billeder af arbejdssituationer, moder og af arbejderlederne er en mangelvare fra 1880'erne. När der findes billeder fra perioden for 1914, vil det typisk vare som det her bragte, hvor man stiller en gruppe op til fotografering, ofte $i$ en anledning, som man ikke mer kan fastslå pracist. Pd̊ billedet overst er varftsarbejdere ("Rikker") hos Flensburger Schifsbau-Gesellschaft fotograferet omkring 1890. Nederst ses skibsbygningsselskabets larlinge fotograferet pd samme tid. Gengivet efter postkort i Schiffahrtsmuseum Flensburg. 

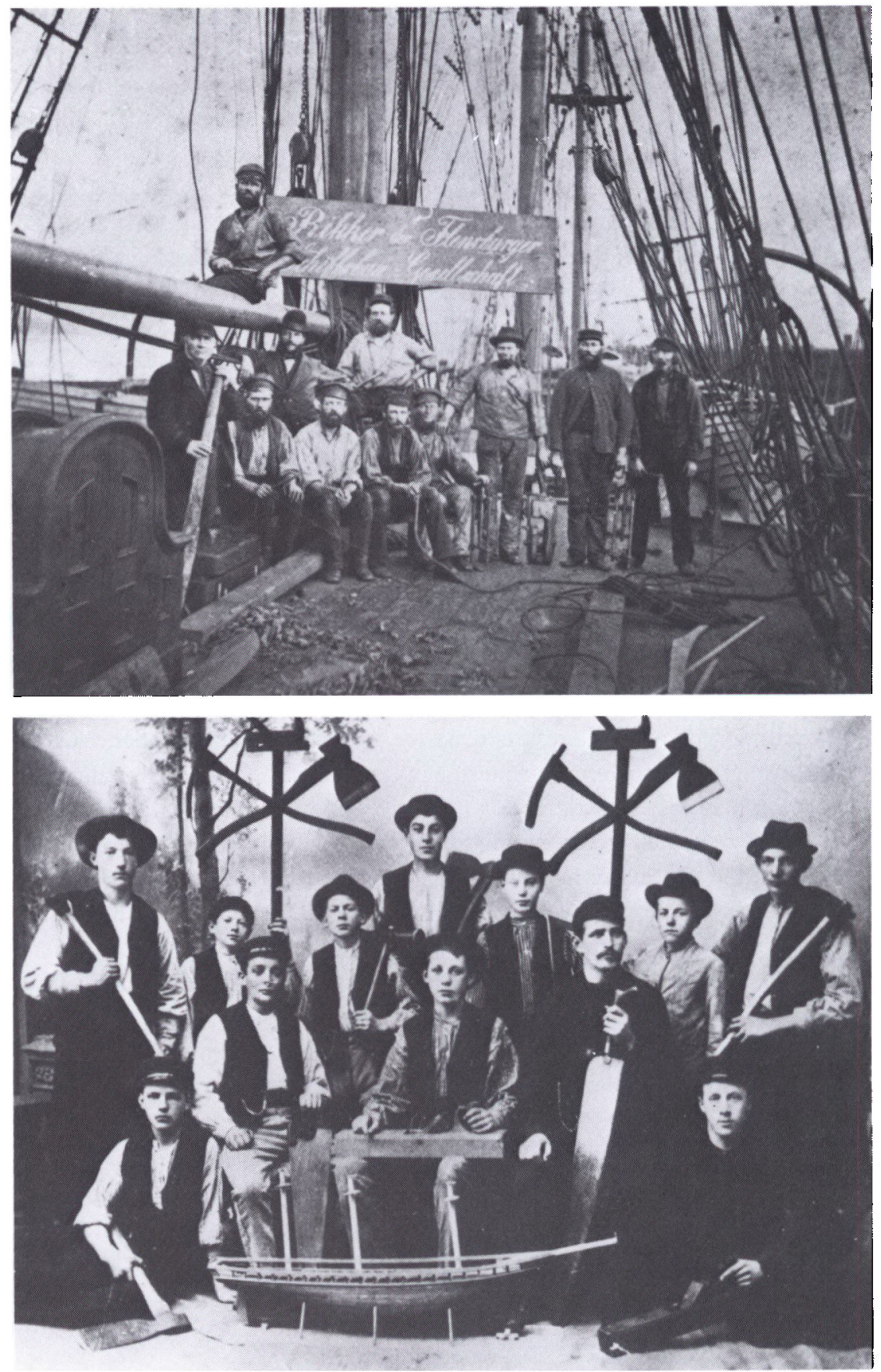
I 1881 opstillede de dansksindede derfor forskellige kandidater $i$ de tre valgkredse.

De dansksindede havde på denne tid ikke nogen organisation til at diskutere og formulere deres politik, idet Valgerforeningen først blev stiftet i 1888, så det er rimeligt at antage, at Johannsens valgopråb er hans eget initiativ, eventuelt efter samråd med de andre danske ledere i Flensborg, ud fra et ønske om at få en mere virkningsfuld appel til byens arbejder- og småkårsstand. Denne linje var der begrænset forståelse for i de udpræget dansksindede egne nordpå. ${ }^{40}$

Men også ved de følgende valg i 2 . kreds i perioden fastholdt og udbyggede Johannsen sit frisindede program, der ikke alene imødekom de dansksindedes og socialdemokraternes opposition mod regeringspolitikken, men også den oppositionelt indstillede del af middelklassen. Det sidste må fremhæves, fordi de frisindede ikke selv opstillede nogen kandidat ved valgene i 2 , kreds før $1890 .{ }^{41}$ I 1886 var hans valgopråb ret detaljeret med oppositionsstandpunkter, og det udsendtes også som tysksproget løbeseddel. Det fastslog som indledning det nationale standpunkt og fortsatte: »Intet monopol, hverken tobaks-, brændevins- eller andet monopol, der skader det frie erhverv, heller ingen ny skat, der skal erstatte monopolet. Ingen undtagelseslov som t.e. Socialistloven. Hemmelig og direkte valgret og betryggelse af valgfriheden. Presse-, forsamlings- og foreningsfrihed. Lighed for loven uden persons anseelse. Ingen toldog økonomipolitik i særinteressers tjeneste. Afkortelse af militærtiden. Forsvar mod alle angreb på folkerepræsentationens rettigheder. Skadesløshedsholdelse for uskyldigt fængslede og dømte. $\kappa^{42}$

I valgkampen 1890 fremhævede Johannsen på et valgmøde i Åbenrå, at de frisindede stod de danske nær i mange henseender. F.eks. ønskede de ligesom Johannsen en nedsættelse af de indirekte skatter, der ramte den wlille mand « hårdt, og afkortelse af militærtjenesten.

Ved et valgmøde i Flensborg den 17. februar 1890 erklærede han ligefrem: "Jeg kalder mig dansk-frisindet. ${ }^{43}$

Ud over eventuelle valgtaktiske hensyn må Johannsens stillingtagen til forskellige indenrigspolitiske spørgsmål nok ses i sammenhæng med striden mellem de såkaldte edsnægtere og edsaflæggere i 1880'erne, mellem de dansksindede, der mente, at den nationale protestpolitik fortsat skulle være det vigtigste, at hævdelsen af den moralske ret til opfyldelsen af $§ 5$ skulle være det dominerende programpunkt, og så dem, der onskede, at det danske parti skulle arbejde for at få konkret indflydelse i rigsdag og landdag for at bekæmpe de dele af lovgivningen, der skadede de dansksindede. Men også i forhold til edsaflæggernes standpunkt gik Johannsen meget langt ved sin stillingtagen til 


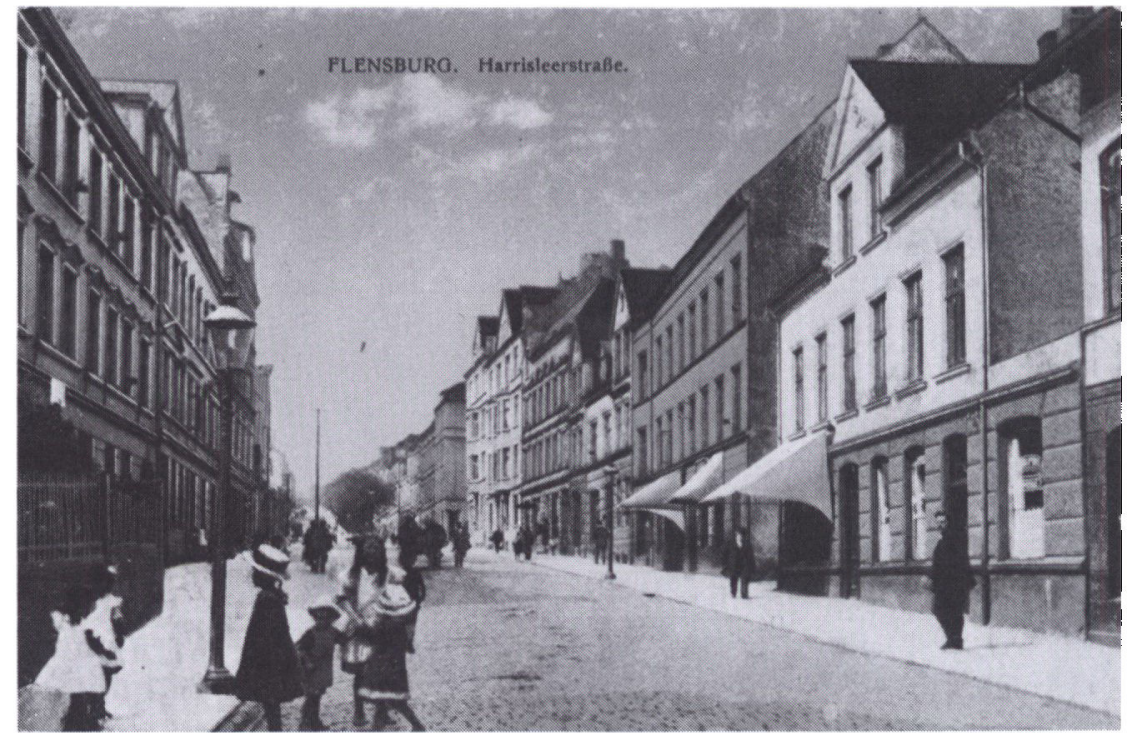

I Harreslevgade var der mange lejeboliger, hvor isar varftets mange arbejdere boede. Flere nye kvarterer så dagens lys i perioden 1864-1910, hvor byen mere end tredoblede sit indbyggertal. (Postkort i Dansk Centralbibliotek for Sydslesvig)

regeringens økonomiske politik og sin kritik af forhold, der ikke havde direkte nationalpolitiske konsekvenser. ${ }^{44}$

\section{Rigsdagsvalg 1881-90}

Gustav Johannsens nyformulering af den danske politik i 1881 førte til kraftige socialdemokratiske angreb. I en korrespondance fra Flensborg til Sozialdemokrat beskyldes han således for bondefangeri, og korrespondenten glæder sig over, at den socialdemokratiske kandidat alligevel har fået omkring 100 stemmer mere end ved sidste valg i $1879 .{ }^{45}$

Ved omvalget med den nationalliberale kandidat sejrede Johannsen efter at have øget sit stemmetal i Flensborg by fra 1328 til 2428 og i Flensborg landkreds fra 640 til 1880 . Valgdeltagelsen ved omvalget var større end ved hovedvalget (11.986 mod 11.062 stemmer). Mens den konservative og den nationalliberale kandidat ved hovedvalget havde fåt tilsammen 6930 stemmer, fik den nationalliberale Francke kun 5576 stemmer ved omvalget, hvor der altså blev afgivet væsentlig færre tyske stemmer. Samtidig steg Johannsens samlede stemmetal fra 3797 til 6410 . Hvorfra og hvorfor fik Johannsen disse stemmer? Han må for det første have fået stemmer fra valgere, der havde 
stemt tysk i første valgomgang. For det andet må det være rimeligt at tro, at der er kommet vælgere til, som ikke havde stemt ved hovedvalget. Det kan være dansksindede, der ikke havde regnet med, at Johannsen havde nogen chance for at blive valgt, dels kan de i hvert fald i Flensborg by være kommet fra vælgere med frisindede sympatier, som ved hovedvalget enten havde stemt på en af de andre tysk-borgerlige kandidater eller slet ikke havde stemt, fordi de ikke havde deres egen kandidat. Den almindelige fremgang for den tyske opposition i Slesvig-Holsten i 1881 taler måske for denne antagelse, og i det hele taget havde den tyske partisplittelse været stor ved dette valg. At man i samtiden forstod, at valget af Gustav Johannsen ikke udelukkende kunne fortolkes som nationalt betinget, fremgik af et brev fra Jens Jessen til Johannsen, hvori han udtrykte ønsket om, at Johannsen i sit fremtidige virke ikke måtte "støde de uundværlige elementer iblandt Deres vælgere, som ikke er vore nationale meningsfaller. $\aleph^{46}$

Ved det næste rigsdagsvalg i 1884 lykkedes det ikke Johannsen at komme på omvalg, selv om hans stemmetal steg i kredsen som helhed. Grunden til, at han ikke blev genvalgt, er nok for en stor del, at der denne gang kun var én tysk-borgerlig modkandidat. Desuden blev der ført en kraftig agitation mod Johannsen med udgangspunkt i hans nære samarbejde på rigsdagen med de frisindede. Endelig steg valgdeltagelsen 1884 til $61 \% \bmod 55,4$ i 1881 . Derfor rakte Johannsens stemmefremgang ikke til at sikre ham et omvalg. Samtiden hæftede sig ved Johannsens tilbagegang i Angel, hvor man mente, at hans modstand mod regeringens levnedsmiddelfordyrende, agrarprotektionistiske politik kunne have kostet stemmer, en advarsel om faren ved at engagere sig i tysk indenrigspolitik, når man repræsenterede vælgere med modstridende økonomiske interesser. ${ }^{47}$

Hvordan forholdt socialdemokraterne sig til omvalgsproblematikken? På partikongressen i Schweiz 1880 blev det vedtaget at anbefale partifællerne at afholde sig fra at stemme ved omvalg mellem to borgerlige kandidater, og denne parole ønskede Flensborgsocialdemokraterne at følge i 1881. Det hævdedes $i$ en korrespondance til Sozialdemokrat, at de fleste havde regnet Johannsen for tilhørende den »reaktionære masse«, 1875-partiprogrammets karakteristik af de borgerlige partier. ${ }^{47}$ Derfor havde socialdemokraterne ikke stemt ved omvalget. Dette hævdedes også af Mahlke i et læserbrev til Kieler Zeitung, hvor han dog giver den indrømmelse, at »følgelig kan der fra socialdemokratisk side kun delvis være stemt på Johannsen. $\aleph^{48}$ Men i øvrigt havde det socialdemokratiske stemmetal ved hovedvalget været så lavt, at selv hvis alle socialdemokrater havde stemt på Johannsen ved omvalget, ville de ikke have kunnet sikre hans valg.

Mens man i 1881 må regne med, at mange danske arbejdere fortsat stemte 
på den danske kandidat, kan man ved valget i 1886 konstatere, at det socialdemokratiske stemmetal i Flensborg by for første gang overgik det danske efter en valgkamp, hvor socialdemokraterne for første gang kunne holde deres egne valgmøder med kandidaten Heinzel. Et møde i Harreslev samlede ca. 100 deltagere og et i Tivoli i Flensborg 15-1600. På begge møder blev foruden den tysk-borgerlige kandidat også Gustav Johannsen stærkt angrebet. Heinzel fremhævede, "at Gustav Johannsen havde lavet sit liberale program efter socialisternes ... "Johannsen havde i sit program »sagt smukke ting om, hvad han ikke ville«, men ikke omtalt, hvad han ville, eller hvorledes han tænkte sig sit program udført. Under samme valgkamp måtte et dansk valgmøde opløses, fordi en del fremmødte socialdemokrater forhindrede en planmæssig afvikling. ${ }^{49}$

Fra valget 1886 steg de socialdemokratiske stemmetal stærkt både i Flensborg by og i landkredsen. Ved valget 1890 blev der for forste gang opstillet en lokal kandidat, nemlig Mahlke. Partiet blev det største i Flensborg by, et tegn på en skærpet social kamp og på, at den nationale bevidsthed ebber ud blandt arbejderne. Hertil kom, at de nationale styrkeforhold i byen var ændret ved en kraftig tilflytning af tysksindede i løbet af 1880 'erne.

I Flensborg landkreds blev der 1890 afgivet socialdemokratiske stemmer i næsten alle valgdistrikter, dog særlig i distrikterne nær Flensborg. I Lyksborg flakke afgaves 48 socialdemokratiske stemmer. I 2. kreds som helhed var socialdemokratiet nu det næststørste parti med 3890 stemmer. Det største parti var det nationalliberale med 6175 stemmer, og den nationalliberale kandidat sejrede da også stort over Mahlke ved omvalget, støttet af de frisindede. Den frisindede kandidat havde fået 2999 stemmer, der næsten udelukkende kom fra Flensborg by og kreds. Gustav Johannsen, der fortsatte som rigsdagskandidat i 2. kreds til sin død 1901, havde fået 3241 stemmer. Det måtte nu stå klart for de fleste, at den danske kandidat i kredsen ikke mere kunne få stemmer nok til at komme på omvalg som i 1881 .

I selve Nordslesvig kunne man i 1890 også se beskedne resultater af socialdemokratisk valgagitation. Bedst klarede partiet sig i Åbenrå kreds, som var i valgkreds med Flensborg, hvorfra partifællerne i det meste af perioden havde forsøgt at holde kontakten ved lige nordpå. I alt gav kredsen 235 stemmer ved hovedvalget.

I 1. kreds koncentrerede de socialdemokratiske stemmer sig om Sønderborg by, teglværksområderne på Broagerland samt Haderslev by og nærmeste opland. De 147 stemmer i kredsen blev formentlig især afgivet af tilvandrede arbejdere. I hvert fald for Haderslevs vedkommende tyder korrespondancer til Nord-Wacht før valget på det. Heri opfordres nemlig til at oplyse de dansktalende kammerater, så de stemmer på arbejderpartiets kandidat. Der 


\section{6.}

Migēoagboalget t 2Den Ilos - igfte 2 algfreb. 3 Folge Jela gram lll Ribaus Bureau or Oot ts

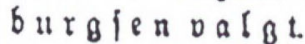

Zetyoningen af bette 23als ligger flet ilfe $i$, at 0 ot burgien er bles Den bu!gt. Djan reprejenterer bet mieg. tige Bisma:dife sigre, ber beb Antorts teternes sigerlp toinger fig igennem. giei, Betybningen ligger $i$, at ben banfe

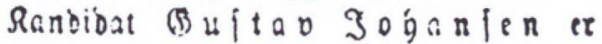
baaet tilbage og Enctaldem ol ra tiets Randtbats setnjelfrem

2li bar i Gaar meboelt nogle i ben senifende oplnjenbe Tal. Sobanjen, ber reprafenterer ben famme enjolbige D.nitheb forn til Etsempel Ingemann qieterfen efler Barberbojen ber bjemme, er fiocil 1884 iflensbors $2 y$ gâaes neb fra $16: 38$ Eteminer til 1024, men Socinlbemolraterne bar ounbet op $f \mathrm{ra}$ 806 til1726, a t tia a tilouer bet bobbelte. $I_{g}$ bellere benne Tilualst for pore Brpore i Tyfilano end en rilbalst for bet Faril, bots jabreland er ben Plat og Rlat, boor Soxet till fremmebe Rationer gris liarlet?.

Bt bar under bisie Emitanbtobeber ingen Betlagelfer tilovers for Sottburg. fens Ralg. Nafte Bang blioer Balget marfe fom oet b t o a re.

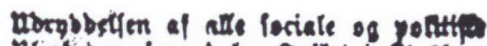
thlighenet. Iom belet jollet i klabiex.

Bafgbag pea en allutubelig gribes.

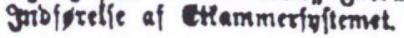

Cratis og offenlig Metsplete.

xhiflaffellen of ben faaento, bar. Subforctien af at alminbeligt jollerart.

Dumar Omfors for Eyge, Samse is Xxbejbsinvaltier vet Staten.

Deligioxen extlares for on privaties.

Valgkommentar i den danske Socialdemokraten 1. april 1886 i anledning af Gustav Johannsens tilbagegang $i$ Flensborg ved rigsdagsvalget. Kommentaren indeholder nogle of te citerede ord: "Og hellere denne tilvakst for vore brodre $i$ Tyskland end en tilvakst for det parti, hvis fadreland er den plet og klat, hvor hadet til fremmede nationer gror starkest."

To dage efter understregede Socialdemokraten, at der ikke var nogen grund for arbejderne til at langes imod provisorietidens Danmark. Valget af en socialdemokrat ville bdde vare en protest mod den uretfardige anneksion af Nordslesvig og 》mod det tyske tyranni, der hver dag udoves af den internationale kapitalisme." De smd slogans $i$ spalten herover stammer fra Socialdemokratens bladhoved. 
advares mod at lade sig lokke til den tyske Bürgervereins møder, hvor arbejderne bliver bestukket med "Freibier « ${ }^{50}$ Også i 1. kreds var kandidaten Mahlke.

I 4. kreds var kandidaten skrædder Friedrich Bentrup fra Flensborg. Han spillede i nogle få år en fremtrædende rolle i partiet i Flensborg, indtil han meldte sig ud i 1894, fordi hans arbejdsgiver ellers ikke ville forfremme ham til tilskærer. ${ }^{51}$ I hele valgkredsen blev der i alt afgivet 315 stemmer. Heraf kom de 32 fra Tønder by og en del fra det senere Sydtønder amt, 23 fra Vesterland og 10 fra Læk. Valgkredsens største socialdemokratiske stemmetal fandtes i Husum by med 124 .

Den socialdemokratiske stemmefremgang i 2 . kreds betød, at den socialdemokratiske kandidat for første gang kom med $i$ et omvalg, denne gang med den nationalliberale skibsreder Jebsen, Åbenrå. Omvalgsproblematikken mellem de danske og socialdemokraterne blev nu aktuel igen, men med modsat fortegn af 1881. De danske stemmer havde en mulighed for at blive udslaggivende til Mahlkes fordel. I den danske lejr var der ikke ganske enighed om holdningen. Imidlertid udsendte Vælgerforeningen et noget tvetydigt opråb om, at de danske skulle afholde sig fra valgdeltagelse og altså ikke stemme på oppositionskandidater, selv om de var »et mindre onde«. ${ }^{52}$ I 4 . kreds kunne opråbet have betydning for valget af en frisindet kandidat. Opråbet var ifølge Vælgerforeningens sekretær H.P. Hanssen »et kompromis. Utydeligheden hidrører fra et forlangende af flere bestyrelsesmedlemmer, der gik ud på, at det skulle affattes således, at folk kunne læse det, som om de skulle blive hjemme, samtidig med, at det ved indrømmelser til den tyske opposition gav vore repræsentanter en gunstigere parlamentarisk stilling. Lassen, og jeg var enig med ham deri, ville have føjet følgende sætning til opråbet: „Vi kan kun råde! Handler efter Eders bedste overbevisning.« Der var i flere egne af Tønder og Flensborg kredse en afgjort stemning for ved omvalget at stemme på de oppositionelle kandidater som det mindre onde .... ${ }^{53}$

Åbenrås danske avis Hejmdal, der ikke er bevaret fra dette tidspunkt, skal have trykt et angiveligt læserbrev fra "En håndværker«, der opfordrede til at stemme på Mahlke, og skal også have vedlagt stemmesedler, for ham, samt have offentliggjort Vælgerforeningens opråb for sent! Landråden indberettede herom til regeringspræsidenten, at kun ved personlig indgriben fra enkelte danske førere blev antallet af de af Hejmdal vildledte ikke af katastrofalt omfang. ${ }^{54}$ Derimod tog dagbladet Dannevirke i Haderslev stærk afstand fra deltagelse $\mathrm{i}$ omvalget og fra Vælgerforeningens opråb. ${ }^{55}$ Dette standpunkt falder i naturlig forlængelse af den modstand nogle af de haderslevske ledere skulle have gjort imod, at Gustav Johannsen i 1886 blev opstillet som rigsdagskandidat i denne kreds efter Junggreens død. De havde stillet det krav, at Johannsen $i$ rigsdagen skulle indtage et rent dansk proteststandpunkt. ${ }^{56}$ 
Den socialdemokratiske fremgang ved omvalget blev alligevel af bemærkelsesværdigt omfang i Åbenråkredsen, idet Mahlkes stemmetal mere end fordobledes i forhold til hovedvalget. Det steg fra 235 stemmer til 546. Det meste af fremgangen skete tilmed på landet, hvor stemmetallet steg fra 189 til 471 . I Flensborgkredsen var forøgelsen af Mahlkes stemmetal ved omvalget procentuelt langt lavere. Fremgangen i Åbenrå kreds skete over en bred front - kun ét valgdistrikt (Skovbølgård) viste tilbagegang i forhold til hovedvalget. Det var embedsmændenes opfattelse, at stemmefremgangen skyldtes de dansksindede. De tysk-frisindede, der havde fået en nyoprettet organisation i valgkredsen før dette valg, har næppe bidraget særligt til den socialdemokratiske omvalgsfremgang, alene af den grund at partiet kun fik 64 stemmer i Åbenrå kreds ved hovedvalget.

Mahlke opnåede dog ikke stemmer nok i 1890 til at blive valgt. Men resultatet var bemærkelsesværdigt. Selv om den danske bevægelse som helhed havde haft et godt valg, så Flensborg ud til at være tabt for danskheden. Efter at Gustav Johannsen i 1886 var blevet valgt til rigsdagsmand for 1. kreds, blev han i stigende grad Nordslesvigs mand og koncentrerede sig i høj grad om de problemer, som regeringens sprogpolitik medførte dér, men som ikke var af særlig interesse i Flensborg by og kreds.

\section{Jens Jessen og arbejderne}

Efterhånden som Gustav Johannsen opslugtes af de nordslesvigske problemer, blev redaktør Jens Jessen danskhedens første mand i Flensborg. Efter Johannsens valg til rigsdagen 1881 havde Jessen overtaget redaktionen af Flensborg Avis, og 1883 blev han også udgiver af bladet. Med sit fremragende journalistiske talent lykkedes det ham i løbet af 1880 'erne at føre Flensborg Avis frem til en ledende position i landsdelen; men fremgangen gjorde sig især gældende i de dansktalende dele af Sønderjylland og modsvaredes ikke af en tilsvarende forøget indflydelse i Flensborgkredsen. I hvert fald formåede Jessen ikke at standse eller vende den for danskheden så negative udvikling her. Personligt var Jessen en type helt modsat Gustav Johannsen, og han manglede dennes folkelige pondus. Han var overbevist protestmand og blev hurtigt protestlinjens mest fremtrædende stemme. Gustav Johannsens frisindede linje stod han i 1880'erne meget skeptisk overfor. I politisk henseende ansås Jessen i almindelighed for højreorienteret, og $\mathrm{i}$ begyndelsen nærede man i danske kredse $\mathrm{i}$ Flensborg frygt for, at den åbenhed, hvormed Jessen udtalte sin sympati for Højre i Danmark, skulle skade abonnenttilgangen til avisen. ${ }^{57}$ Men det må i denne sammenhæng betones, at Jessens sympatier for politiske partier især styredes af hans vurdering af, om deres politik tjente de danske slesvigeres interesser, og hans sympati for det danske Højre var i høj grad bestemt af 
dets holdning til forsvarsspørgsmålet. Principperne for det partipolitiske liv i Danmark havde Jessen formentlig ingen dybere forståelse af eller interesse for. ${ }^{58}$

Socialismen som ideologi afviste Jessen ligesom de andre danske førere, og han fremhævede ofte med afsky, at partiet ville afskaffe religion og ægteskab. ${ }^{59}$ De kræfter i samfundsudviklingen, der betingede socialismens fremvækst, forstod han næppe helt styrken af. I Jessens bevidsthed overskyggede det nationale problem det sociale, og med beklagelse og undren så han, at også danske arbejdere tænkte omvendt. I en leder i Flensborg Avis efter valget 1886 tumlede han således med problemet: "På grund af arbejdsløsheden og nøden i den lange, hårde vinter er den største del af arbejdsklassen denne gang draget over i socialisternes lejr. Mange af dem har ved dette brud med deres fortid trøstet sig ved, at det ikke havde nogen videre praktisk betydning, da de jo ved at stemme på den socialistiske kandidat ligefuldt ville medvirke til at muliggøre et omvalg, ved hvilket de så altid kunne stemme på hr. Gustav Johannsen. Den moralske betydning, det har, at de har unddraget vor kandidat deres stemmer, er der næppe tænkt meget på. ... Det er en dyb sorg og skuffelse for os, at arbejderstanden så let har kunnet lade sig bevæge til at lade os i stikken.« Senere funderede Jessen videre over problemet, hvorfor socialdemokraterne havde så let ved at vinde gehør blandt arbejderne, og hans patriarkalsk-

Annonce kort for 1. oktober 1889 for J.Jessens lille tysksprogede avis, Flensburger Zeitung. Han häbede hermed at nå det store ikke-dansktalende publikum, herunder dele af arbejderbefolkningen $i$ Flensborg. (Flensborg Avis' arkiv pk. 3. Dansk Centralbibliotek for Sydslesvig)

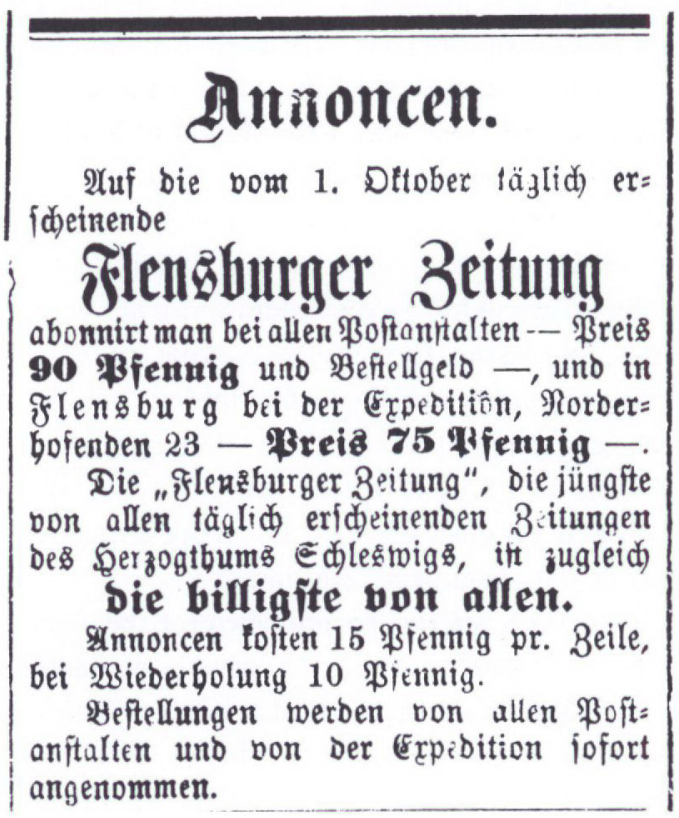


nedladende holdning skinner her igennem: "Deres lange udviklinger finder taknemmelige tilhørere blandt den store hob, der naturligvis ikke kan have forudsætningerne til at anvende den fornødne kritik.« Men samtidig yder Jessen arbejderlederne en lidt modvillig anerkendelse: »De tyske socialdemokrater har desuden den fordel, at deres forere vistnok i det hele og store er hæderlige mænd, der kæmper for deres overbevisning og derfor på en måde er værdige til både den agtelse og den hengivenhed, som arbejderne viser dem. " $^{61}$

En hovedanke, Jessen havde mod socialdemokraterne, var, at de i det hele taget deltog i rigsdagsvalgene i 2 . kreds med deres egen kandidat. Denne kreds betød så lidt $\mathrm{i}$ den store tyske sammenhæng, men så meget for de danske. ${ }^{62}$ Uanset hans personlige modvilje mod den socialistiske ideologi, var hovedsagen for Jessen nemlig, at socialdemokratiet var et tysk parti, hvis virksomhed skadede den danske, nationale sag. I 1885 ironiserer Flensborg Avis over, at socialdemokraterne var blevet erklæret uønskede ved et møde for "tyske og rigstro vælgere«. "Hvorfor kan en tysk socialdemokrat ikke være tysk og rigstro? Hvis de tyske socialister kunne få deres planer virkeliggjorte inden for det tyske riges ramme, så har de vistnok ikke noget imod at være særdeles rigstro. Så længe de kun arbejder for en fredelig og lovordnet forandring af tilstandene, kan man næppe engang frakende dem ret til at kalde sig forfatningstro. ${ }^{63}$ Det var en meget fremsynet udtalelse om det tyske socialdemokrati; men artiklen er måske især bemærkelsesværdig ved sin afstandtagen fra regeringspartiernes hetz mod socialdemokratiet som et parti, der tilstræbte en voldelig ændring af samfundsforholdene.

I det hele taget kan argumentationen mod socialdemokratiet i Flensborg Avis ikke sidestilles med den hadefulde og usandfærdige propaganda, der førtes i den tyske, borgerlige presse. Jessen ønskede at vinde arbejderne, ikke at støde dem fra sig, selv om han ikke var særlig behændig hermed. Før valgene aftryktes de socialdemokratiske valgopråb i deres helhed i Flensborg Avis, og Jessen forsøgte at opstille en national, ofte stærkt følelsesbetonet modargumentation for at fastholde arbejderstemmerne. Personlige angreb på arbejderlederne forekom ikke. På valgmødet i Harreslev 21. marts 1886, hvor R.P.Rossen fra Flensborg Avis tog ordet, skal Mahlke også have indrømmet, at tonen i Flensborg Avis var bedre end i Flensburger Nachrichten og Flensburger Norddeutsche Zeitung. ${ }^{64}$

Efter den stærke socialdemokratiske fremgang ved valget 1886 dukkede Jessens planer op om at få udgivet et dansksindet blad på tysk. „Vi har jo ikke noget som helst middel til påvirkning af hele den store flensborgske arbejderstand undtagen hr. Gustav Johannsens person. Den kan i længden ikke magte hele byen, « skrev Jessen i et privat brev. ${ }^{65}$ Det kneb imidlertid med 
at skabe økonomisk baggrund for planen, bl.a. var forståelsen for behovet ikke stor blandt Jessens økonomiske forbindelser i Danmark. Først i 1889 lykkedes udgivelsen af Flensburger Zeitung, der udkom tre gange om ugen $i$ begyndelsen, og fra 1 . oktober samme år som dagblad, indtil bladet måtte standses den 1. juli 1894.

Flensborgsocialdemokraterne advarede i Die Nord-Wacht arbejderne mod bladet. Det var ikke upartisk som hævdet, og man skulle ikke tro, at redaktionen ville varetage arbejderinteresser. Bladet kostede kun $75 \mathrm{pfg}$. i kvartalet, og med den pris var det »selvfølgeligt, at intet fornuftigt kan tilbydes, for den som vil bringe noget ordentligt, må lade sig sit arbejde betale«, hed det, sikkert

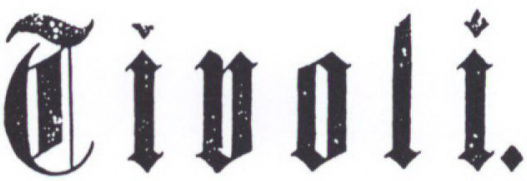

\section{Mai, Abendis i Ulir,}
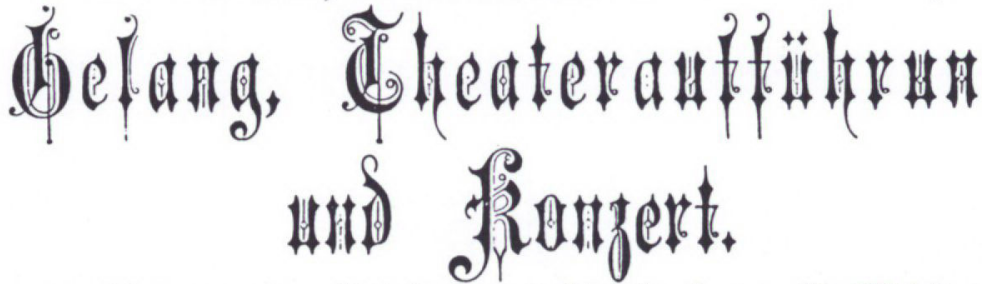

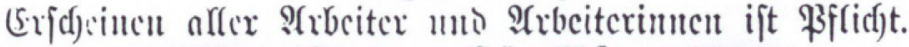

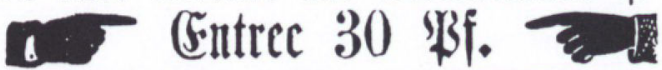

\section{Mühlenpavillong}

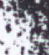

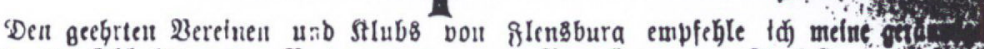

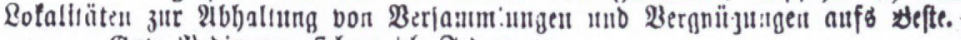

Butte bebienang fid)ere tdf Sedult zu.

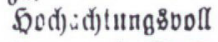

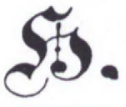

Diciel

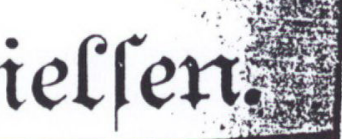

To annoncer fra 1890. I den overste indkaldes til den forste 1.maj-fest $i$ Flensborg $i$ Tivoli. Nedenunder reklamerer et andet populart etablissement Mollepavillonen for, at foreningerne skal holde forsamlinger og forlystelser dér. - Selv om Socialistloven endnu ikke var udløbet, var arbejderbevagelsen efterhdinden så etableret, at der ikke mere lagdes store hindringer $i$ vejen for modevirksomheden. (Gengivet efter 1. Mai 1890. Festzeitung der Arbeiterschaft Flensburgs. Aabenraa byarkiv II 8,2 Landsarkivet, Aabenraa.) 


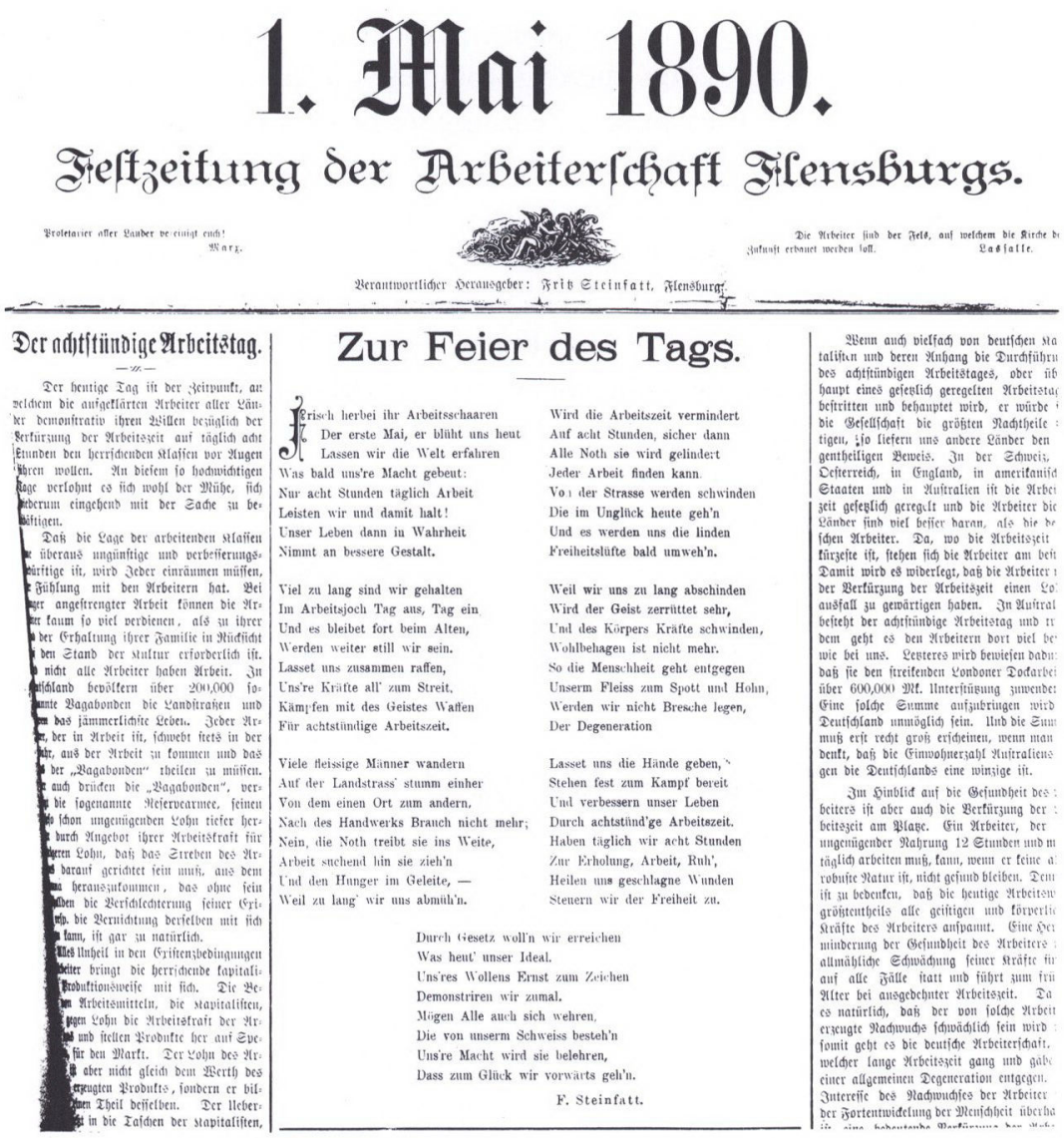

Fra forsiden af Flensborgarbejdernes 1.maj-avis, der blev trykt i Matzens bogtrykkeri i Aabenraa. Som udgiver er anfort Fritz Steinfatt, der var cigarfabrikant og boede i Flensborg i nogle år omkring 1890. Ved rigsdagsvalget tidligere på året havde han kandideret $i$ 9. kreds (Oldenburg m.m.). Han står også som forfatter til forsidedigtet, der lyser af optimisme og sejrsbevidsthed. I sidste vers understreges, at arbejderne vil nå deres mål med lovlige midler. (Landsarkivet i Aabenraa, Aabenraa byarkiv II 8,2.)

med en hentydning til Jessens vægring tidligere på året mod at betale trykkerne efter tariffen. ${ }^{66}$

Lige i begyndelsen gik det rimeligt med Flensburger Zeitung; men snart løb den ind i permanente vanskeligheder. Egnede folk lykkedes det ikke at få knyttet til redaktionen, og Jessen måtte selv bruge megen tid på avisen. I 1890 kunne han ærgre sig over, at bladledelsen $i$ hans fravær havde udsendt et gratis prøvenummer, hvori der var trykt en ledende artikel vendt imod kravet om 8timers arbejdsdagen og "to mindre artikler med brod mod socialismen!«, selv om Jessen havde anbefalet »det yderste mådehold politisk og socialt. $\aleph^{68}$ Efter 
Socialistlovens udløb 1. oktober 1890 kom desuden den stærke konkurrence fra den nye arbejderpresse, der hurtigt udviklede sig, og socialdemokraterne advarede fortsat arbejderne mod bladet med henvisning til Jessens negative holdning til fagbevægelsen. ${ }^{69}$

Alt i alt må man nok sige, at initiativet med Flensburger Zeitung kom alt for sent til at kunne bremse arbejdernes overgang til socialismen. Var avisen kommet i Socialistlovens første år, hvor tysk, socialdemokratisk presse var helt lammet, havde den måske haft en større chance; men dengang havde den danske bevægelse ingen forestilling om, hvor hurtig den flensborgske arbejderbefolknings overgang til socialdemokratiet ville blive.

Det er givet, at den konservative Jens Jessen ikke var den bedste mand, den danske bevægelse kunne have til at føre kampen om de danske arbejderstemmer i Flensborg. Men på den anden side lykkedes det heller ikke for den folkelige og politisk frisindede Gustav Johannsen at fastholde arbejderne. Den udvikling, der førte til, at arbejderne i Flensborg foretrak den sociale kamp for den nationale, var formentlig uafvendelig på længere sigt, uanset hvem de danske førere i Flensborg var. Alene den befolkningsmæssige udvikling i byen i 1880 'erne med den stærke indvandring sydfra måtte virke negativt for danskhedens stilling, og hertil kom, at det var det tyske socialdemokrati og den tyske fagbevægelse, der mest konsekvent varetog arbejdernes politiske og økonomiske interesser.

\section{Afslutning}

Ved Socialistlovens ophør i 1890 var status i det nordlige Slesvig således, at der $\mathrm{i}$ den voksende industriby Flensborg fandtes en allerede ret stærk arbejderbevægelse politisk og fagligt. Derimod havde selve Nordslesvig ikke haft en økonomisk og befolkningsmæssig udvikling i 1880'erne, der begunstigede udviklingen af en egentlig arbejderklasse. I de kommende år blev arbejderbevægelsens udvikling da også ganske træg, selv om Flensborgpartifællerne fortsatte agitationen nordpå med samme entusiasme som i Socialistlovens sidste tid.

Et vidnesbyrd om arbejderbevægelsens voksende selvbevidsthed var det, at der i 1890 blev holdt 1. maj-møder i Haderslev, Åbenrå og Flensborg. Anden Internationale havde på sin kongres i Paris 1889 vedtaget, at 1 . maj skulle fejres af arbejderne som en helligdag og bruges til demonstrationer, især for indførelsen af 8-timers arbejdsdagen. I Tyskland var der stor betænkelighed ved at lade arbejdet hvile hele dagen af frygt for, at de deltagende arbejdere ville blive afskediget. Møderne i Åbenrå og Haderslev fandt da også sted uden 
for arbejdstiden. I Flensborg opgav man en oprindelig opfordring til at holde fri på dagen og opfordrede i stedet til at fejre dagen fra kl. 16, wifald det da ikke bliver til skade for arbejdsforholdet «. Om aftenen blev der holdt en stor fest i Tivolihaven med ca. 1500 deltagere, hvor der var underholdning med koncert, sang, teater og recitation. Desuden var der salg af en stor "Festzeitung der Arbeiterschaft Flensburgs «. ${ }^{71}$

Fra Lyksborg berettedes til Nord-Wacht, at man også her i bogstaveligste forstand havde forsøgt at vise flaget. Tidligt om morgenen blev der hængt en rød fane op i den store kongeeg ved slotsdammen med indskriften "Acht Stunden " ( 8 timer) "... som et vidnesbyrd om, at selv på ikke anede steder har arbejderen forstået sin klassesituation og med glæde er beredt til at sætte alt ind for folkets befrielseskamp fra trykkende lænker. ॥ $^{72}$

For den danske bevægelse var det heller ikke i de følgende år uden betydning, om arbejderbevægelsen skulle få fremgang på hidtil wikke anede steder «. Det kunne koste danske stemmer ved valgene og i det hele taget virke som en fortyskningsfaktor. Særlig efter århundredskiftet debatteredes problemerne i forbindelse med rigsdagsvalgkampene. Fra dansk side ønskede man, at socialdemokraterne påvirkede de danske arbejdere til at stemme dansk ved hovedvalgene, så der kunne ske en national mønstring. Men dette opnåedes ikke. Socialdemokratiet prioriterede nemlig den sociale solidaritet frem for den nationale i denne sammenhæng. I 1912 var den socialdemokratiske stemmeandel i Nordslesvig på lidt over $8 \%$ med tyngdepunktet i købstæderne, hvor også fagbevægelsen var ret veludviklet. Det politiske gennembrud for socialdemokratiet i Nordslesvig skulle imidlertid først komme efter Genforeningen.

\section{Bilag}

Socialdemokratiske stemmetal i 1., 2. og 4. slesvig-holstenske rigsdagsvalgkreds under Socialistloven.

1. kreds (Haderslev-Sonderborg)

\begin{tabular}{lccc} 
& $\begin{array}{c}\text { 15. okt. } \\
1886\end{array}$ & $\begin{array}{c}21 . \text { feb. } \\
1887\end{array}$ & $\begin{array}{c}20 . \text { feb. } \\
1890 .\end{array}$ \\
\hline Haderslev by & & 9 & 23 \\
Øvrige Haderslev kreds & & & 8 \\
Haderslev kreds ialt & $?$ & $?$ & 31 \\
Sønderborg by & & & 38 \\
$\emptyset v r i g e$ Sønderborg kreds & & & 78 \\
Sønderborg kreds ialt & $?$ & $?$ & 116 \\
Hele 1. kreds & 7 & 12 & 147 \\
(Først en officiel socialdemokratisk kandidatur ved valget 1887 ) & \\
\hline
\end{tabular}


2. kreds (Åbenrå-Flensborg)

\begin{tabular}{lrrrr} 
& 21. nov. & 27. okt. & 28. okt. & 29. marts \\
& 1879 & 1881 & 1884 & 1886 \\
\hline Flensborg by & 235 & 333 & 806 & 1726 \\
Flensborg landkreds & 15 & 16 & 108 & 541 \\
Flensborg kreds ialt & 250 & 349 & 914 & 2267 \\
Åbenrå by & 2 & 0 & 6 & 19 \\
Øvrige Åbenrå kreds & 2 & 4 & 0 & 0 \\
Ábenrå kreds ialt & 4 & 4 & 6 & 19 \\
Hele 2. kreds & 254 & 353 & 920 & 2286 \\
\hline
\end{tabular}

2. kreds (forts.)

\begin{tabular}{lrrr} 
& $\begin{array}{c}21 . \text { feb. } \\
1887\end{array}$ & $\begin{array}{c}\text { 20. feb. } \\
1890\end{array}$ & $\begin{array}{c}1890 \\
\text { (omvalg) }\end{array}$ \\
\hline Flensborg by & 1917 & 2543 & 2840 \\
Flensborg landkreds & 752 & 1112 & 1608 \\
Flensborg kreds ialt & 2669 & 3655 & 4448 \\
Abenrå by & 13 & 46 & 75 \\
Øvrige Åbenrå kreds & 29 & 189 & 471 \\
Ábenrå kreds ialt & 42 & 235 & 546 \\
Hele 2. kreds & 2711 & 3890 & 4994 \\
\hline
\end{tabular}

\section{4. kreds (Tonder-Husum-Ejdersted)}

\begin{tabular}{cccc}
$\begin{array}{c}\text { 27. okt. } \\
1881\end{array}$ & $\begin{array}{c}\text { 28. okt. } \\
1884\end{array}$ & $\begin{array}{c}\text { 21. feb. } \\
1887\end{array}$ & $\begin{array}{c}20 . \text { feb. } \\
1890\end{array}$ \\
& & 0 & 32 \\
0 & 0 & 1 & 71 \\
& & 1 & 103 \\
23 & 5 & 13 & 212 \\
isk kandidatur ved valget 1890) & 315 \\
\hline
\end{tabular}




\section{HENVISNINGER OG NOTER}

Af pladsmæssige hensyn bringes der ikke nogen komplet liste over den omfattende litteratur, der kan have betydning for emnet. Interesserede henvises til den udførlige bibliografi af Klaus-J. Lorenzen-Schmidt i Arbeiter und Arbeiterbewegung in Schleswig-Holstein im 19. und 20. Jahrhundert. Hrsg. von Rainer Paetau und Holger Rüdel. Neumünster 1987.

Forkortelser i henvisninger:

Ark $=$ arkiv

LAS $=$ Landesarchiv Schleswig-Holstein, Slesvig

LA $\AA$ = Landsarkivet for de sønderjyske landsdele, Ábenrå

F BArk = Flensborg byarkiv (i Stadtarchiv Flensburg)

H BArk $=$ Haderslev byarkiv $(\mathrm{i}$ Haderslev byhistoriske Arkiv)

S BArk = Sønderborg byarkiv (i LAA)

$\AA$ BArk = Åbenrå byarkiv (i LAÅ)

For byarkivernes vedkommende drejer henvisningerne sig om afdelingerne efter 1867.

FA $=$ Flensborg Avis

NW $=$ Die Nord-Wacht. Wochenblatt für das arbeitende Volk

SjyÅrb = Sønderjyske Årbøger

1. Akter herom i LAS Abt 309: 327 og 328. Også Karl Frohme: Politische Polizei und Justiz im monarchischen Deutschland, Hamburg 1926, s. 55, H. Laufenberg: Geschichte der Arbeiterbewegung in Hamburg, Altona und Umgegend, Bd. 2, Hamburg 1932, s. 468ff, NW 27.10.1889. Efter sin løsladelse flyttede Kückelhahn til Flensborg, hvor han fortsatte sin virksomhed for arbejderbevægelsen.

2. Om udviklingen før 1878 se f.eks. Dorrit Andersen: Die Gründung und die ersten Jahre der Flensburger Arbeiterbewegung 1868 bis 1878 (s. 321 -338 i Flensburg. 700 Jahre Stadt, Flensburg 1984) og Gerd Callesen: Die Arbeiterbewegung in Nordschlesvig 1872-1878. Hauptzüge ihrer Entwicklung (s. 193-216 i Zeitschrift der Gesellschaft für schleswig-holsteinische Geschichte, 100, 1975).

3. Diverse landråds- og politiindberetninger i LAS Abt 309: 311 og 221.

4. Sozialdemokrat 16.1 .1881 .

5. FA 5. og 10.12.1978. Döll blev senere kendt som fortaller og foredragsholder $i$ den tyskborgerlige arbejderforening, Arbeiterbund i Flensborg, i afholdsforeninger og veteranforeninger.

6. Die Sozialdemokratische Partei in Kiel. Ihre geschichtliche Entwicklung. Bearbeitet von Wilhelm Brecour, Kiel 1932, s. 24. LAS Abt 309: 1263, løbeseddel "Mit sidste Ord til Apenrader Zeitungs Redaktor « (skrevet i slutningen af $1882 \mathrm{i}$ anledning af en polemik mellem de to aviser).

7. Gert Rossberg: Heinrich Mahlke - Reichstagsabgeordneter aus Flensburg (s. 161-171 i Demokratische Geschichte III, 1988).

8. Diverse omtale i Wilhelm Ewalds pjece Fünfundzwanzig Jahre "Socialdemokratischer Verein in Apenrade«: Sonderabdruck aus dem "Apenrader Tageblatt«, 1926.

9. Å BArk II, 8, 2, LAS Abt 309: 229, Åbenrå landråd 19.9.1889.

10. Første gang Haderslev NW 14.10.1888, Åbenrå 20.4.1889, Tønder 22.9.1889.

11. Sozialdemokrat 14.7.1881, LAS Abt 309: 313, Flensborg politiforvaltning 8.6.1881.

12. LAS Abt 309: 331, Flensborg politiforvaltning 13.12.1888, NW 16.12.1888.

13. NW 28.10.1888.

14. NW 14.4.1889, LAS Abt 309: 226, Haderslev landråd 15.3.1887, og 227, do. 10.9.1887.

15. Diverse om foreningsdannelser i Haderslev i H BArk 42, 2c, og LAS Abt 309: 231, Haderslev landråd 15.6.1890.

16. NW 20.4., 11.5.1890.

17. Diverse i S BArk II, 2, 3, LAS Abt 309: 12544, Sønderborg landråd 29.9.1890, Tønder landråd 25.9.1890, og 230 do. 21.3.1890.

18. LAS Abt 309: 231, Protokoll des Siebenten Kongresses der Maurer Deutschlands. 
19. LAS Abt 309: 317, Flensborg politiforvaltning 30.3.1886.

20. NW 9.12.1888 - 17.2.1889, F BArk I, J 26, 2, Flensburger Schiffsbau-Gesellschaft 23.11.1888, 9.2.1889.

21. Om J. Jessens forhold til typograferne: Flensborg Avis 1869-1969, 1969, s. 172f, FA 27. og 29.3., 10.4.1889, NW 26.5., 18.8 og 8.9.1889, 24.7.1892.

22. NW 15.12.1889; LAS Abt 309: 230, Flensborg politiforvaltning 14.12.1889, 2.4.1890.

23. Å BArk II, 8, 2, Politiforvaltningen i Åbenrå 10.12.1884.

24. FA 7. og 12.10.1884, LAS Abt 309: 236, Flensborg politiforvaltning 6.10.1884.

25. FA 29.3.1886.

26. LAS Abt 309: 12540, Sønderborg landråd 2.4.1890.

27. En kortfattet oversigt over den politiske udvikling i Slesvig-Holsten som helhed, herunder oversigter over rigsdagsvalgene, kan findes i Uwe Danker: Die Geburt der Doppelstrategie in der "Roten Hochburg«, Arbeiterbewegung in Schleswig-Holstein 1863-1918 (s. 20-62 i Demokratische Geschichte III, 1988).

28. H.P. Hanssen: Gustav Johannsen som parlamentariker (s. 71-76 i Fra Kampaarene I, 1927).

29. J.P.Junggreen til P.A. Madvig 23.4.1886, trykt i SjyÅrb 1938, s. 322.

30. Stenographische Berichte über die Verhandlungen des deutschen Reichstages 1884-85, s. 934.

31. Biografi i Demokratische Geschichte III, 1988, s. 190-192 (Karl-Rudolf Fischer).

32. FA 29.3.1886.

33. FA 22.3.1886.

34. FA 5.2.1887.

35. FA 22.3.1886.

36. Om udviklingen efter 1890 se bl.a. Gerd Callesen: Die Schleswig-Frage in den Beziehungen zwischen dänischer und deutscher Sozialdemokratie von 1812 bis 1924. Ein Beitrag zum sozialdemokratischen Internationalismus. Schriften der Heimatkundliche Arbeitsgemeinschaft für Nordschleswig, Heft 21, Apenrade 1970, og Dorrit Andersen: Socialdemokrati og dansk-national bevægelse. Omkring det slesvig-holstenske SPD's 1902-resolution (s. 123-144 i Historie, Ny række XIII, 1979). Samme: National og social solidaritet. Chr. Mathiesen - en arbejderfører i granselandet. Festskrift til Johan Hvidtfeldt, 1978, s. 1-22.

37. Opråbet findes i \& BArk II, 8, 2, og LAS Abt 309: 320.

38. FA 12.10 .1881 .

39. FA 25.10.1881.

40. F.eks. J. Jessen til Gustav Johannsen fra Haderslev 12.11.1881: "... det kan jo ikke nægtes, at ikke alle har varet enige om at billige et valgopråb, i hvilket det nationale skubbedes i baggrunden ..... Gustav Johannsens privatarkiv 7, LAA.

41. I Flensborg by blev der ganske vist i 1887 afgivet 121 stemmesedler med den frisindede Albert Hänels navn; men han var ikke officielt opstillet.

42. FA 25.3.1886, løbeseddel i Gustav Johannsens privatarkiv 15, LA $\AA$.

43. FA 4. og 19.2.1890.

44. Hans Lassen, rigsdagsmand for 1. kreds $1881-84$, delte Johannsens opfattelse. Det kom f.eks. frem på det danske opstillingsmøde i Vojens 20.9.1884, FA 23.9.1884.

45. Sozialdemokrat 17.11.1881.

46. J. Jessen til Gustav Johannsen 15.11.1881, Gustav Johannsens ark 7.

47. Sozialdemokrat 13.4.1882.

48. Oversattelse af Mahlkes brev i FA 22.11.1881.

49. FA 29.3.1886.

50. NW 12., 26.1, 9.2.1890.

51. LAS Abt 309: 239, Flensborg politiforvaltning 4.4.1894.

52. Trykt i FA 27.2.1890.

53. H.P.Hanssen til J.N.H.Skrumsager 6.3.1890, J.N.H.Skrumsagers ark, LA\&, Breve fra forskellige.

54. LAS Abt 309: 12540, Å benrå landråd 26.3.1890.

55. Dannevirke 25., 27. og 28.2.1890, sst. indlæg af S. Amorsen imod socialdemokratiet 18.2. 
56. Hans Lassen til Gustav Johannsen 28.8.1886, Gustav Johannsens ark 8, LAA.

57. Chr.Monrad til T.A.J.Regenburg 4.1.1883, Regenburgs ark, breve fra forskellige, Rigsarkivet.

58. Avisartiklen FA 26.1.1886 "Bergs dom og fængsling", trykt i Redaktør Jessen i Tale og Skrift, 1921, s. 151-155, viser tydeligt, hvorledes Jessen tolker begivenheder i Danmark ud fra sine egne erfaringer fra den nationale kamp i Sønderjylland. Således konkluderes den i en frygt for, at de danske retstilstande skal komme til at ligne de tyske.

59. F.eks. FA 18.2.1887.

60. FA 30.3.1886.

61. FA 5.4.1886.

62. FA 18.2.1887.

63. FA 1.1.1885.

64. FA 22.3.1886.

65. J. Jessen til Carl Herold 6.4.1886, citeret efter A.Svensson: Redaktør J. Jessen, I, 1955, s. 217.

66. NW 20.10.1889.

67. Flensburger Zeitung er ikke bevaret. Enkelte aktstykker om den findes i FA's ark 3, Dansk Centralbibliotek for Sydslesvig. - Se i øvrigt nærmere s. 46f i Redaktor Nis Petersens erindringer fra Flensborg Avis 1889-97, SjyÅrb 1973.

68. Flensborg Avis 1869-1969, 1969, s. 127f, J.Jessen til Carl Herold 15.5.1890.

69. F.eks. NW 21.12.1891.

70. FA 30.4.1890.

71. Et ekspl. heraf findes i $\AA$ BArk II, 8, 2.

72. NW 18.5.1890. 